\title{
İcrai Olmayan İşlem Türlerinden Yol Gösterici İşlemin Hukuki Değeri
}

\author{
The Legal Value of the Guiding Administrative Act Types of Non-Executive \\ Administrative Acts
}

\author{
Hulüsi Alphan Dinçkol ${ }^{*}$ (D)
}

\section{öz}

İdare, idari faaliyetlerin yürütülmesi bakımından birçok işlem ve eylem icra etmektedir. Ancak bazı işlemler doğrudan kişi ya da eşyalar üzerinde etki yaratmayabilir. İcrai olmayan idari işlemler olarak adlandırılan bu işlemlerden birisi de, yol gösterici işlemdir. Toplumu ve ilgili idareleri aydınlatma, bu bağlamda idari faaliyetlerin yapılabilmesi noktasında belirleyici olması ve idarenin iç işleyişi bakımından etki üretmesi amacıyla tesis edilen yol gösterici işlemler, kimi zaman sorulan bir soru üzerine, kimi zaman ise resen tesis edilebilirler. Yol gösterici işlemler, belirli bir hususta işlemi tesis eden idarenin görüş ve fikrini ortaya koyarlar. Her ne kadar ilgililer ya da idareler üzerinde dolaylı bir etki yaratsa da bu işlemlerin doğrudan icrai bir niteliği bulunmaz. İcrai etkilerinin ortaya çıkabilmesi için bir idari işleme ihtiyaç duyarlar. Yol gösterici işlem türünün alt türlerinin ise ağırlıklı olarak doktrindeki görüşler doğrultusunda şekillendiği gözlenmektedir. Özellikle tanımlama bakımından çeşitli yönler doktrinde ele alınmıştır. İdari yargı kararları ise, türün tespitini yaparken, daha çok icrailik konusu üzerinde durmuştur. 2577 sayılı İdari Yargılama Usulü Kanunu’nun ilk inceleme hükümlerince dava şartı olarak işlemin icrailiği üzerinde durulması, yargının uygulaması bakımından bağlayıcı bir durum ortaya çıkarmıştır. Ancak yargı kararlarında icrai olmayan işlemlerin alt gruplarına değinilmese de, alt grupların tespit edilmesi önem arz etmektedir. İlgililer, kendileri hakkında tesis edilen yol gösterici işlemlerden doğrudan etkilenmeseler de, dolaylı yoldan etkilenebilirler. Bu nedenle kendileri hakkında uygulanacak icrai işlemlerin gerekçesi olacak yol gösterici işlemler ile ilgili inceleme yapılmasını talep hakları, hukuk devleti ilkesi gereğince bulunacaktır.

Anahtar Kelimeler: Yol Gösterici İşlem, Aydınlatma Yükümlülüğü, İcrai Olmayan İdari İşlem, İdari Yargı, İptal Davası.

\section{ABSTRACT}

The administration executes many transactions and acts in terms of carrying out administrative activities. However, some actions may not directly affect people or things. One of these acts, which are called non-executive administrative acts, is the guiding acts. Guiding acts which are established for the purpose of enlightening the society and the relevant administrations at the point of being able to carry out administrative activities, can be exercised sometimes upon a solution to a question or sometimes ex officio. Guiding acts reveal an opinion or a thinking of the administration that established this action on a particular issue. Although it creates an indirect effect on the related parties or administrations, it does not have a direct executive quality. They need an administrative act in order to maintain their executive effects. The sub-types of the guiding act types are mainly tried to be shaped by the views in the doctrine. Especially in terms of the definition are discussed with the various aspects with the doctrine. On the other hand, administrative judicial decisions are focused more on the issue of execution power of administrative act while determining the type. Emphasizing the execution of the act as a condition of action in the first review provisions of the Procedure of Administrative Justice Act (no: 2577) has created a binding situation in terms of the implementation of the judiciary. Although subgroups of non-executive transactions are not mentioned in judicial decisions, it is important to identify subgroups. The persons concerned are not directly affected by the guiding acts established for them, though they may be affected indirectly. For this reason, people has the right to demand an examination regarding the guiding acts that will be the reason for the enforcement acts to be applied against them will be found in accordance with the principle of the rule of law.

Keywords: Guiding Act, Obligation of Enlightenment, Non-executive Administrative Act, Administrative Justice, Action for Annulment.

* $\quad$ Dr. Öğr. Üy., Maltepe Üniversitesi Hukuk Fakültesi İdare Hukuku Anabilim Dalı, ORCID: 0000-0001-5698-4449.

Sorumlu Yazar/Correspondence Author: Hulüsi Alphan Dinçkol

E-posta/E-mail: alphandinckol@maltepe.edu.tr

Geliş Tarihi/Received: $\quad 24.08 .2021$

Kabul Tarihi/Accepted:

05.12 .2021 


\section{Giriş}

İdari işlem kavramı hakkında yapılan incelemelerde ilk akla gelen kavramlardan birisi, işlemin "icrailiği” kavramıdır. İlgililer üzerinde doğrudan etki yaratması nedeniyle idari yargıya taşınan idari işlem, doğrudan iptal davasının konusu yapılabilir. Ancak idare hukukumuz bakımından icrai işlem tek başına tüm idari işlem grubunu temsil etmez.

İdare, faaliyetlerini yürütürken bazı durumlarda, kimsenin ya da hiçbir eşyanın üzerinde tek başına hukuki bir etki yaratmayacak işlemler tesis edebilir. Bu işlem türü, icrai olmayan işlem olarak adlandırılmaktadır. İcrai olmayan işlem, idari yargıda tek başına iptal davasına konu edilemeyen ve ilgililer üzerinde etki yaratabilmek için başka bir işleme ihtiyaç duyan bir işlemdir. Bu işlem çeşitli biçimlerde kendini gösterebilmektedir. Bu işlem türü, idarenin iç işleyişini sağlayan bir biçimde ortaya çıkabilirken, kimi durumlarda da icrai bir işlemin tesis edilebilmesi için öncelikle tüketilmesi gereken bir şekil şartı olabilmektedir. Kimi durumlarda ise ilgililere yol gösterme amacıyla, onların soruları üzerine ya da resen tesis edilebilirler. Çalışmanın esası bakımından incelenecek olan icrai olmayan işlem türü ise icrai olmayan yol gösterici işlemdir.

Yol gösterici işlemler birçok biçimde tesis edilebilirler. Ancak bu işlemlerin temel amacı "ilgilileri aydınlatma"dır. İdare, görüş veya fikirlerini, kendisine sorulan sorular üzerinden ilgilere ya da topluma sunabilecekken, herhangi bir soruya bağlı kalmaksızın resen de duyuru yapabilmektedir. İyi yönetim ilkesi bakımından idarenin bilgilendirme fonksiyonu önem arz eden bir ödevdir. Bu ödevin gereği gibi yerine getirilebilmesi için yol gösterme fonksiyonunun idarece kullanılması zaruridir.

Çalışma kapsamında yol gösterici işlemin icrai olmayan işlem türleri arasındaki yeri ortaya konulmaya çalışılacak; diğer icrai olmayan işlemlerden farklılığının belirlenebilmesi için yol gösterici işlemin alt türleri tespit edilecektir. Ayrıca idari yargının bakış açısı doğrultusunda konuya ilişkin içtihatlar irdelenecektir.

\section{YOL GÖSTERICi işLEM VE IDARi işLEM TÜRLERI ARASINDAKI YERi}

\section{A. YOL GÖSTERICI IŞLEMIN ARASINDA BULUNDUĞU ICRAI OLMAYAN IŞLEM GRUBU}

İdare, idari faaliyetlerini yerine getirirken birçok hukuki işlem ve eylemin tesis edilmesine ihtiyaç duyar. Kimi zaman idari işlem ve eylemle sonuca ulaşmaya çalışırken, kimi zaman ise özel hukuk işlemlerine başvurur. İdarenin günlük ölçekte bu faaliyetleri yerine getirirken kullandığı bazı idari işlemlerin, faaliyetlerin devamlılığı bakımından önemi bulunmasına rağmen kişiler ya da eşyalar üzerinde doğrudan bir etkisi bulunmayabilir. Dolayısıyla idarenin bu tip işlemler tesis etmesinin kişiler ve eşyalar bakımından doğrudan hukuki bir sonuç doğurmayacağı da açıktır ${ }^{1}$. Bu kapsamda, kişi veya eşyaların hukuki durumunu icrai olarak etkilemeyen, hukuk âleminde herhangi bir değişim

Turan Yıldırım, Melikşah Yasin, Nur Kaman, H. Eyüp Özdemir, Gül Üstün ve Özge Okay Tekinsoy, İdare Hukuku (Güncelleștirilmiş 7. Baskı, Oniki Levha Yayıncılık 2018) 336. 
oluşturmayan işlem türüne, “icrai olmayan işlem” denilmektedir². Duran bu işlem türünü, “idari karara benzeyen işlem” olarak adlandırmaktadır³.

İcrai olmayan işlemler, hukuk düzeninde kişiler ya da eşyalar üzerinde doğrudan etkiye sahip değildirler. Söz konusu bu işlemler, idarenin iç işleyişine dair olabilir ya da icrai bir idari işlemin hazırlayıcısı olabilirler ${ }^{4}$. Bunlarla beraber kimi zaman idare, kendi faaliyet alanına ilişkin bir görüş, yol gösterici bir öneri, fikir ya da tanıyı, kendine sorulan bir soru üzerine ya da resen incelemesi sonucunda beyan edebilir ve bu işlemi, başka bir icrai işlemin dayanağı olabilir. Belirtilen tüm bu işlemlerin ortak yönü ise tesis edildikleri zaman bağımsız ve tek başlarına icrai bir rol üstlenememeleridir.

İcrai olmayan işlemlerin idari işlem niteliği bulunmadığı görüşü doğrultusunda, idarenin sadece hukuki sonuç doğuran tek yanlı işlemlerini idari işlem olarak nitelendiren Yaylaya göre; "hukuki sonuç doğurmayan, henüz bir uyuşmazlık yaratmayan idare işlemleri, "icrai ve dava konusu olabilir" işlemler değildir: hazırlık, görüş bildirme, öneri, tavsiye gibi muamele ve asıl işlemin aşamaları tek başlarına idari işlem olarak kabul edilmezler" ". Yayla çeşitli işlemleri bu kapsamda sayarken, bu işlemlerin sadece esas işlemden ayrılarak dava konusu edilebilmesi halinde idari işlem sıfatına bürünebileceğini belirtmektedir ${ }^{6}$. Bu yoruma karşın icrai olmayan işlemleri idari işlem türü olarak saymamanın, idarenin faaliyetleri bakımından bazı olumsuz etkilere yol açabileceğini düşünebiliriz. Özellikle kimi icrai işlemin sebep unsuru olabilecek icrai olmayan işlemin, icrai işleme karşı açlacak davayı inceleyen idari yargı mercii tarafından göz ardı edilebileceği sonucu ortaya çıkabilecektir. Bu husus, çalışmada inceleme altına alacağımız olası durumlardan biri olarak karşımıza çıkmaktadır.

İcrai idari işlemlerin en ayırt edici özelliği, terimin isminde de yer alan icrailik özelliğidir. İcrailik

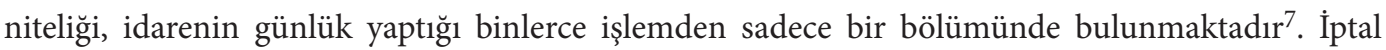
davasına doğrudan konu edilemeyecek olan geri kalan icrai işlemlerin ise ayrıca incelenmesi gerekir. İcrai olmayan bu işlemlere karşı açılan iptal davalarının ilgili idari yargı yerince ilk inceleme safhasında reddedilmesi durumu gerçekleşmektedir ${ }^{8} .2577$ sayılı İdari Yargılama Usulü Kanunu’nun

2 Bahtiyar Akyılmaz, Murat Sezginer ve Cemil Kaya, Türk İdare Hukuku (12. Baskı, Savaş Yayınevi 2020) 336; Celal Erkut, İptal Davasının Konusunu Oluşturma Bakımından İdari İşlemin Kimliği (T.C. Danıştay Yayınları No: 51 2015) 163; Kemal Gözler, İdare Hukuku Cilt: I (İkinci Baskı, Ekin Yayınevi 2009) 703; Yıldırım, Yasin, Kaman, Özdemir, Üstün ve Okay Tekinsoy (n 1) 336; Oğuz Sancakdar, Lale Burcu Önüt, Eser Us Doğan, Mine Kasapoğlu Turhan ve Serkan Seyhan, İdare Hukuku Teorik Çalıșma Kitabı (Seçkin Yayınevi, Eylül 2019) 314; Onur Karahanoğulları, İdarenin Hukukla Kavranması: Yasallık ve İdari Işlemler (Yargı Kararlarına Dayalı Bir Inceleme) (4. Baskı, Turhan Kitabevi 2018) 261 vd. Kimi eserlerde bu işlem türü, "etkisi olmayan işlem", "karar olmayan işlem” olarak adlandırılmaktadır: Turgut Tan, İdare Hukuku (Turhan Kitabevi, Eylül 2013) 230; Hasan Nuri Yaşar, İdare Hukuku (Genel Esaslar) (Der Yayınevi 2014) 262; Cemil Kaya, 'Türk İdare Hukukunda İcrai Olmayan İdari İşlemler' (2004) 9(1-2) Gazi Üniversitesi Hukuk Fakültesi Dergisi 253, 260; Bige Açımuz, 'İdarenin Esnek Hukuk İşlemlerinin Yargısal Denetime Konu Edilmesi: Fransız Hukuku Odaklı İnceleme’ (2018) 24(2) Marmara Üniversitesi Hukuk Fakültesi Hukuk Araştırmaları Dergisi 530, 538.

3 Lütfi Duran, İdare Hukuku Ders Notları, (Fakülteler Matbaası 1982) 397.

4 Dilşat Yılmaz, İdari İşlemin İcrailik Özelliği (Astana Yayınları 2014) 65.

5 Yıldızhan Yayla, İdare Hukuku (2. Basım, Beta Yayıncılık Eylül 2010) 109.

6 Yayla (n 5) 109.

7 Erkut (n 2) 163.

8 Kaya, 'Türk İdare Hukukunda İcrai Olmayan İdari İşlemler’ (n 2) 254. 
14 ve 15. maddeleri kapsamında yetkili ve görevli idari yargı yeri, icrai olmayan ve ayrıca kesin olmayan ve yürütülmesi gerekmeyen işleme karşı açılan iptal davasını doğrudan reddetmektedir ${ }^{9}$. İdari Yargılama Usulü Kanunu’nun 14 ve 15. maddelerinin beraber incelenmesi bu bağlamda önemlidir.

İdari Yargilama Usulü Kanunu’nun 14. maddesinde yer alan; "İdari davaya konu olacak kesin ve yürütülmesi gereken bir işlem olup olmadiğg" ifadesi, bir işleme karşı idari yargıya başvurabilme bakımından önem taşır. Öncelikle yürütülebilir bir işlem kavramı ile icrailiğin ifade edildiğini belirtmemiz gerekir ${ }^{10}$. Özellikle kamu gücünün kullanılması bakımından tek taraflı iradesinin yeterli olması, idarenin icrai bir işlem tesis etmesini sağlamaktadır. Bu güce dayanılarak tesis edilen işlemin çeşitli hukuki sonuçlar doğurması da, icrai nitelikte aranan bir diğer özelliktir ${ }^{11}$. Herhangi bir işleme tabi olmaksızın hukuki etki yaratan icrai işlemin kaynağının nereden geldiğinin ise belirtilmesi lazımdır. Kamu yararı adına idari faaliyetlerde bulunarak işlem tesis eden idarenin icrai işlem tesis edebilmesindeki kaynak da bu bakımdan açıktır. İdarece tesis edilen idari işlemler, kamu yararı amacından gelmektedir ${ }^{12}$. Kamu yararı amacından gelmemekle birlikte etkili olabilen işlemler hem icrai işlem sayılamazlar hem de böyle bir durum hukuk devleti niteliğine uygun değildir. Her ne kadar yargı denetimi söz konusu olsa da bir hukuk devletinde idare, kullandığı yetkinin nitelik ve sinırları konusunda yönetilenlere güvence vermek durumundadır. Kamu otoritelerinin ancak hukuken yetkilendirildiklerinde ve yetki sınırları çerçevesinde faaliyet yapabilmeleri gerekir. $\mathrm{Bu}$ davranış devletin hukuksal meşruiyetini de güçlendirir.

Kesinlik kavramı, hukuk düzeninde farklı anlamlarda kullanılmaktadır ${ }^{13}$. Ancak kesinlikkavramından anlaşılması gereken hususun tek olması gerekir. İdari bir itirazın öngörülmediği ve idari işlemin sonuçlandığı anlamına gelen kesinlik, yargı yolunun kapalı olduğu anlamına gelmemektedir ${ }^{14}$. Erkut işlemin bu durumunu; "işlemin uygulanmaya hazır, tamam (nihai) bir işlem olduğunu göstermekte" olduğu şeklinde açıklamaktadır ${ }^{15}$.

Danıştay, kesin ve yürütülebilir işlem kavramını, "işlemin tamamlanmasına yönelik idarî usûl kuralları uygulanarak yetkili kamu görevlisi veya görevlileri tarafından imzalanı bu durumuyla uygulamaya konulan ve kendi başına hukukî sonuçlar doğurarak idarenin tek taraflı ve emredici gücüne dayanan

9 İdari Yargılama Usulü Kanunu, Kanun Numarası: 2577, Kabul Tarihi: 06.01.1982, RG 20.01.1982/17580’nin “Dilekçeler üzerine ilk inceleme" başlıklı 14/III-d maddesi kapsamında idari davaya konu olacak kesin ve yürütülmesi gereken bir işlem olup olmadığ ilk incelemeye tabidir. Yine 2577 sayılı Kanunun "İlk inceleme üzerine verilecek karar" başlıklı 15/Ib maddesi kapsamında ilk inceleme safhasında idari davaya konu olamayacak bir işlemin tespit edilmesi sonucunda davanın reddedilmesi gerekmektedir.

10 Murat Sezginer, İptal Davasını Uygulama Alanı Bakımından Ayrılabilir İşlem Kuramı (Yetkin Yayınları 2000) 43.

11 Erkut (n 2) 144.

12 Yllmaz, İdari Iş̧lemin İcrailik Özelliği (n 4) 32. İcrailik, diğer bir deyişle yürütülebilirlik kavramları bakımından detaylı bilgi için bakınız; Erkut (n 2) 144; Sezginer (n 10), 43.

13 Dilşat Yılmaz, 'Türk İdare Hukuku’nda İdari İşlemin "Kesinliği” Üzerine Bir Değerlendirme: "Kime Göre?”, "Ne İçin?" Kesinlik' (2017) 21(2) Gazi Üniversitesi Hukuk Fakültesi Dergisi 105, 111.

14 Bahtiyar Akyılmaz, Murat Sezginer ve Cemil Kaya, Türk İdari Yargılama Hukuku (4. Baskı, Savaş Yayınevi 2020) 298.

15 Erkut (n 2) 146. Kesinlik kavramı bakımından detaylı bilgi için bakınız; Erkut (n 2) 146 - 147; Yılmaz (n 10) 109. 
işlem anlamına gelmekte" tanımlamasıyla ifade etmektedir ${ }^{16}$. Tanımlamadan da anlaşılacağı üzere, bir işlemin kesin ve yürütülebilir olmasında, kendi başına hukuki sonuç doğurmaya yönelik oluşu ve ilgili idarenin tek taraflı kamu gücüne dayanması hususları ön plana çıkmaktadır.

İcrai olmayan işlemler her ne kadar idari yargıda doğrudan dava konusu olamasalar da idarenin işleyişine egemen ilkelere göre tesis edilmektedirler ${ }^{17}$. Yetki ve şekilde paralellik ilkesi gibi kimi ilkelerin doğrudan icrai olmayan işlemlere de uygulanması gerekmektedir. Bu durum aslında, idari işlem sınıflandırması bakımından icrai olmayan işlemlerin incelenmesinin önemini arttırmaktadır.

Tesis edilen hukuka uygun icrai olmayan işlemlerin yanı sıra, hukuka aykırı olarak tesis edilen çeşitli icrai işlemlerin de icrailik niteliklerini kaybedebileceğini belirtmek gerekir. Yetkisiz idarelere yapılan başvurular sonucu tesis edilen idari işlemlerin icrai olmayan işlemler olduğu açıktır ${ }^{18}$. Bu kapsamda hem doktrin hem de yargı kararları fikir birliği içerisindedir ${ }^{19}$. Ağır ve açık hukuka aykırı yetki tecavüzü ile tesis edilmiş idari işlemler de bu kapsamda ilgililer üzerinde icrai bir etki yaratmayacaktır. Örneğin özel bir idari kolluk yetkisinin tanınmış olduğu kamu kurumu dışında başkaca bir kamu kurumunun açık ve ağır yetki tecavüzü ile yetkisiz biçimde tesis edeceği idari işlemin icrailiğinin bulunmayacağı kesindir. Aynı doğrultuda yokluk ile sonuçlanacak fonksiyon gaspı ile tesis edilecek işlemlerin de, icrai olmayacağını belirtmek gerekir. Örneğin yasal düzenleme yapılması talebine karşı idare tarafından verilecek cevaba karşı da dava açılamayacaktır ${ }^{20}$.

Önemle belirtmek gerekir ki, somut olayların değişkenliği, bir idari işlemin icrai etkisinin tespitinde yol göstermektedir. İdari işlemden ayrı olarak kendine özgü bir hukuka aykırılık taşıyan uygulama işleminin, somut olayın özelliğine göre iptal davasına konu olabileceği açıktır ${ }^{21}$.

İdarenin işlemlerinin isimlerine bakarak icrai olup olmadığını tespit etmeye çalışmak hem zor hem de sakıncalı olabilecektir. Dolayısıyla bir idari işlemin icrai bir işlem olup olmadığını tespit etmek için ortaya çıkaracağı hukuki sonucu incelemek gerekir²2. Diğer bir deyişle iptal davasına konu edilebilecek bir idari işlem olup olmadığının tespiti, icrai olmayan işlem kategorisinin sınırlarının çizilmesini sağlayacaktır.

İcrai olmayan işlem türleri üç ana başlık altında toplanmaktadır. Bunlar; yol gösterici işlem, hazırlık işlemi ve iç düzen işlemdir ${ }^{23}$.

Danıştay 2 D, E 2008/849 K 2010/255, 29.01.2010.

Yıldırım, Yasin, Kaman, Özdemir, Üstün ve Okay Tekinsoy (n 1) 336-337.

Kaya, 'Türk İdare Hukukunda İcrai Olmayan İdari İşlemler’ (n 2) 259; Yılmaz, İdari İşlemin İcrailik Özelliği, (n 4$) 65$.

Detaylı bilgi için bakınız; Kaya, ‘Türk İdare Hukukunda İcrai Olmayan İdari İşlemler’ (n 2) 259-260.

Yılmaz, İdari İslemin İcrailik Özelliği, (n 4) 65.

Mutlu Kağıtçığlu, 'İdari İşlemin İcrailiği’ (2012) 103 Türkiye Barolar Birliği Dergisi 267, 281.

Erkut (n 2) 163.

Bu işlemleri Duran, gösterici işlemler, hazırlayıcı işlemler ve iç düzen işlemleri olmak üzere üç gruba ayırır; Duran (n 2) 398-399. Aynı doğrultuda doktrinde aynı gruplandırma yapılmaktadır; Tan (n 2).230; Yıldırım, Yasin, Kaman, Özdemir, Üstün ve Okay Tekinsoy (n 1) 336; Metin Günday, İdare Hukuku (İmaj Yayınevi 2011) 124. Giritli/Bilgen/Akgüner/ Berk ise gösterici işlem grubunu bildirici ve beyan edici işlemlere ayırmaktadır; İsmail Giritli, Pertev Bilgen, Tayfun Akgüner ve Kahraman Berk, İdare Hukuku (5. Baskı, Der Yayınevi 2012) 812. Akyılmaz / Sezginer / Kaya da bildirici işlem grubunu, icrai olmayan işlem grubunun bir ayrı alt başlı̆̆ı olarak ele almıştır; Akyılmaz, Sezginer ve Kaya, İdare Hukuku (n 2) 342. 


\section{B. YOL GÖSTERICI işLEM}

\section{YOL GÖSTERICILIK KAVRAMI}

Belirli bir faaliyetin yapılabilmesi ya da bir işin görülebilmesi için yol / yordam göstermek idarenin pozitif yükümlülüklerinden biri olarak karşımıza çıkmaktadır. İdarenin bu pozitif yükümlülügünü ifade ederken, yol gösterici düşünce açıklamalarının ilgili idarenin kendi faaliyet alanlarıyla sınırlı olması gerektiğinin de belirtilmesi lazımdır.

Yol göstermek fiili, Türk Dil Kurumu tarafından mecazi anlamda; "ne yapılacağını, nasıl davranılacă̆ını ögretmek” olarak ifade edilmektedir ${ }^{24}$. Yol gösterici işlemlerin özünü anlamak için yol göstericilik deyimini bu açıdan ele almak gerekir.

İdarenin belki de en önemli görevlerinden birisi, toplumu aydınlatma, bilgi sunma yükümlülügüüür. $\mathrm{Bu}$ yükümlülüğün idari usul ilkelerine yerleşmesi, hukuk devletinde görülecek idari faaliyetlerde kullanılması zorunluluğunu da beraberinde getirmektedir. Akyılmaz’a göre idareye, faaliyetlerinde yürütmesi gereken idari usul ilkeleri kapsamında iki yükümlülük verilmiştir; "yol gösterme yükümlülügüu” ve "bilgilendirme yükümlülüğü"25. Bu iki yükümlülükten yol gösterme yükümlügü, açık bir şekilde anlaşılacağı üzere idarenin tüm başvuruculara yol gösterme niteliğini belirtmektedir. Gerekli hallerde ilgililere hak ve görevlerini bildirme şeklindeki yükümlülük ise bilgilendirme yükümlülüğü olarak karşımıza çıkmaktadır²6.

Bu iki yükümlülüğe ek olarak Avrupa Parlamentosu tarafından 06.09.2001 tarihinde kabul edilen Avrupa İyi Yönetim Kodu bir yükümlülüğü daha gündeme getirmiştir; "bireyin haklı beklentilerine uygun davranmak" 27 . Tabi bu durumda haklı beklentinin nasıl tanımlanacağ 1 da önemlidir. Boz, haklı beklentiyi; "idarenin belirli yönde hareket edeceği hususunda idareden sadır bir tasarruf sonucunda oluşan, bireyin idareye olan güveninin, bazı durumlarda uygun bir görüşme ortamında usuli bir korumayla, bazı durumlarda ilgilisine idareye karşı kendi lehinde bir tasarrufta bulunulmayı talep etme imkânının tanındığı esas korumayla sağlanan, bazı durumlarda ise tazminat yoluyla karşılanan bir menfaat/çıkar elde etme beklentisi” olarak ve bizim de katıldığımız bir şekilde tanımlanmaktadır ${ }^{28}$. Toplumdaki bireylerin menfaatlerinin korunması bakımından haklı beklentinin korunması da, idari usul ilkeleri arasında kendisine yer bulmaktadır.

Yol gösterme ve hukuki yardımın önemini tespit eden merkezi idare, bu hususta tüm idarelerin kullanması gereken bazı esaslar üzerinde çalışmıştır. Bu doğrultuda Bakanlar Kurulu tarafından hazırlanan Kamu Hizmetlerinin Sunumunda Uyulacak Usul ve Esaslara İlişkin Yönetmelik ${ }^{29}$

24 <https://sozluk.gov.tr/> Erişim Tarihi 19.06.2021.

25 Bahtiyar Akyılmaz, İdari Usul İlkeleri Işı̆̆ı̆nda İdari İşlemin Yapılış Usulü (2000) 130.

26 ibid 130.

27 Akyılmaz, Sezginer ve Kaya, İdare Hukuku (n 2) 531.

28 Haklı beklenti kavramına ilişkin incelemeler bakımından detaylı bilgi için bakınız; Selman Sacit Boz, İdare Hukukunda Haklı Beklentinin Korunması (Seçkin Yayıncılık 2017) 42.

29 Kamu Hizmetlerinin Sunumunda Uyulacak Usul ve Esaslara İlişkin Yönetmelik, Bakanlar Kurulu Karar Numarası: 
yürürlüğe konulmuştur ${ }^{30}$. Yönetmeliğin "Kurum içi ve kurum dışı yazışma” başlıklı 11. maddesi uyarınca; "Kurum içi ve kurum dışı görüş, bilgi ve belge talep yazıları günlü yazılır. İlgili mevzuatındaki özel hükümler saklı kalmak kaydıyla, idareler belge taleplerini en geç beş gün, bilgi ve görüş taleplerini ise en geç onbeş gün içinde yerine getirir. İdare, bilgi ve görüş yazıları için onbeş günü geçmemek üzere ek süre kullanabilir. Bu yazışmalar elektronik ortamda da yapılabilir”. Hükümden de anlaşılacağı üzere, ilgili idarelerin kendilerine danışılan konularda görüş bildirme yükümlülüklerinin var olduğu kesindir. Ayrıca cevap süresinin de, 2577 sayılı İdari Yargılama Usulü Kanunu’nda belirtilen otuz günlük süreden daha az olduğu görülmektedir. Yönetmeliğin idarelere kamu hizmetlerinin sunulması konusunda yol gösterici bir etkisi olacağının yanı sıra, düzenleyici bir işlem olması sebebiyle buna aykırı işlem ve eylemde bulunmadan kaçınmaları için de zorlayıcı bir unsur niteliği taşıdığı açıktır.

\section{YOL GÖSTERICI işLEMININ NITELIĞi}

Mevzuatta bir zorunluluk koşulu aranmasa bile, idarenin bir konuya ilişkin düşüncesini açılaması, kendisine sorulan bir soruyu cevaplaması veya gelecekteki bir düzenleme hakkında bilgi vermesi gerekebilir. Bu kapsamda işlemlerin niteliği de, icrai olmamaktadır. Belirtilen türdeki idarenin bu işlemleri, kendilerine yöneltilen sorulara cevap ya da resen yapılan açıklama şeklinde ortaya çıkabilmektedir. Farklı türde tebliğ ya da ilan edilseler bile bu tür işlemlerin icrai nitelikte olmadığını belirtmek gerekir ${ }^{31}$.

İdareye yapılan bir başvuru üzerine ya da idare tarafından resen hazırlanan öneri, fikir ve görüşler doğrudan bir bağlayıcılığa sahip değildirler. Bu nedenle bu işlemlerin idari karar niteliğinde olmadığı da ayrıca belirtilmelidir ${ }^{32}$.

Bu işlem türünde idare, belirli bir konu veya sorun ile ilgili fikrini, niyetini, düşüncesini, görüşünü ve tasarılarını açıklamaktadır. Kimi zaman idarenin bu fikirleri, sonradan düzenleyici işleme dönüşebilirken, kimi zaman ise birel işlem olarak tebliğ edilebilirler ${ }^{33}$.

Yetkili idari birimlerin danışma iradesi olup olmamasına bakılmaksızın hiyerarşi ilişkisinin doğal sonucu olarak bu işlemlerin düzenlenebildiği de görülmektedir ${ }^{34}$. Bu yöndeki yol gösterici işlemler, hazırlık işlemlerinde yer alan zorunluluk unsuruna sahip olmaktadırlar. Buradaki amaç, belirli bir konunun açıklığa kavuşması veya uygulamada birliğin ilgili idare tarafından sağlanmasıdır.

Yol gösterici işlem türü incelenirken, hazırlık işlemi niteliğindeki rapor, görüş ve tutanak işlemleri kapsam dışında tutulmalıdır. Mevzuat kapsamında alınması zorunlu ya da ihtiyari görüş veya raporların tesis edilmesi, tesis edilen bu işlemlerin "hazırlık işlemi” olduğunu göstermektedir. Hazırlık

2009/151169, Karar Tarihi: 29.06.2009, RG 31.07.2009/27305.

30 Yönetmelik ile ilgili detaylı görüşler için bakınız; Akyılmaz, Sezginer ve Kaya, İdare Hukuku (n 2) 531.

31 Yılmaz, İdari İşlemin İcrailik Özelliği, (n 4) 66.

32 Yaşar (n 2) 263.

33 Kaya, 'Türk İdare Hukukunda İcrai Olmayan İdari İşlemler’ (n 2) 269.

34 Erkut (n 2) 174. 
işlemi türünde olan bu görüş ve raporların alınmasından sonra bu işlemlerdeki görüşlere uyulmadan icrai işlemlerin tesis edilmesinde bile, görüş ve raporların hazırlık işlemi niteliği değişmeyecektir ${ }^{35}$.

\section{YOL GÖSTERICi işLEMIN TÜRLERi}

Yol gösterici işlem, tesis edilme sebebi, işlemin konusu, tesis edilme şekli, tesis eden idarenin türü veya tesis edilme ile ulaşılan sonuç bakımından çeşitli alt türlere ayrılabilmektedir. Alt türlere ayrıştırma ile yol gösterici işlemin, diğer icrai olmayan idari işlemlerden farklılığı ortaya çıkmaktadır. $\mathrm{Bu}$ farklılı̆̆ın ortaya konmasındaki önem ise, kendilerine bağlanarak tesis edilecek icrai işlemlerin unsurlarının incelenmesinde önem arz etmeleridir.

Yol gösterici işlemler, diğer icrai olmayan işlemlerden ayrılabilmeleri açısından, "teklif niteliğinde yol gösterici işlem", "cevap niteliğinde yol gösterici işlem" ve "bildiri / duyuru / açıklama niteliğinde yol gösterici işlem” şeklinde üçlü kategoride incelenmektedir.

\section{A. TEKLIF NITELIĞINDE YOL GÖSTERICI IŞLEM}

Bir idarenin içerisinden ya da dişından gelen bir teklif, kimi zaman bir idari işlemin tesis edilmesini sağlamaktadır. Bu teklif, idari teşkilat içerisinde yer almayan gerçek ya da tüzel kişilerden gelebileceği gibi her bir kamu tüzel kişiliğinin her bir biriminden de gelebilmektedir.

Teklif niteliğindeki yol gösterici işlem, teklif yapılan idareyi, bu konuda bir icrai işlem yapma ya da yapmamaya ilişkin karar almaya yönelten ve icrai olmayan bir işlem türüdür. Söz konusu işlem, aynı kamu tüzel kişiliği içerisinde bulunan birimler arasında tesis edilebileceği gibi, farklı kamu tüzel kişileri arasında da gerçekleşebilecektir. Teklif niteliğindeki yol gösterici işlemin tesis edilebilmesi için ilgili mevzuatta, işlemin yapılmasına yönelik bir hükmün açıkça bulunmasına ihtiyaç yoktur. Diğer bir deyişle teklif işleminin bir mevzuat hükmüne dayalı olarak tesis edilmesinde zorunluluk bulunmamaktadır.

Danıştay da teklif niteliğindeki yol gösterici işlemlerin icrai niteliği olmadığını belirtmektedir. Danıştay tarafından verilmiş olan bir kararda bu husus üstünde durulmuştur. Karara konu edilen somut olayda, disiplin soruşturması kapsamında oluşturulan disiplin cezası önerisinin yanı sıra, İl Milli Eğitim Disiplin Kurulu’nca ilgili memurun başka bir yere atanmasına yönelik teklif de idari yargının önüne gelmiştir. İl Milli Eğitim Kurulu’nun disiplin cezası önerisine ek olarak memurun atanmasına ilişkin teklifi, teklif niteliğinde yol gösterici işlem kapsamında düşünülmelidir. Danıştay bu doğrultuda atama teklifi işlemi hakkında; "görüş belirten bir işlem olup, ortada kesin ve icrası lazım gelen bir karar yoktur" kararı vermiştir ${ }^{36}$. Atama konusunda yetkisi bulunmayan İl Milli Eğitim Disiplin Kurulu’nun bu hususta görüş bildirmesi, icrai niteliği olmayan fakat ilgili idari birime icrai bir işlem tesis etmesi yönünde bilgi sunmaktan öteye geçemez. Yine Danıştay bir diğer kararında

35 Akyılmaz, Sezginer ve Kaya, İdare Hukuku (n 2) 337.

36 Danıştay 5 D, E 1972/7204 K 1976/2153, 19.04.1976. 
da, tesis edilen teklif niteliğindeki yol gösterici işlemin idari davaya konu olamayacağı üzerinde durulmuştur. Merkezi idarenin müfettişleri tarafından düzenlenen teklif işlemlerinin idari davaya konu edilmeyeceğinin belirtildiği kararda; "Danıştay'da iptal davası açılabilmesi için iptali istenen işlemin kesin ve yürütülmesi gereken bir işlem olması gerektiği idare hukukunun en belirgin ilkesidir... Müfettişlerce düzenlenen teftiş layihası Belediye Nizamnamesi uyarınca, layihada belirtilen tenkit ve tavsiyeler Belediye Meclisinden geçirildikten sonra yürütülmesi gereken bir karar olabilecektir" hükmüne varılmıştır ${ }^{37}$.

Hazırlık işlemi niteliğindeki teklif işlemi ile teklif niteliğindeki yol gösterici işlemi birbirinden ayırmak gerekir. Asıl nitelikteki bir icrai işlemin hazırlayıcısı olarak tesis edilen teklif işlemi, yol gösterici işlem gibi doğrudan iptal davasına konu edilemez ${ }^{38}$. Benzer oldukları bu husus dışında, neden olacakları ana icrai işlemin oluşmasında farklı yöne sahiptirler. Hazırlık işlemi niteliğindeki tekliflerin, ana işlemin yapılabilmesi bakımından zaruri bir şekil şartı olmaları söz konusudur. Diğer bir deyişle teklif, eğer ilgili mevzuat gereği bir icrai işlemin tamamlanabilmesi adına zorunlu ise, bu durumda kendisinin bir hazırlık işlemi olduğundan bahsedilmesi gerekecektir. Bu nedenle icrai işlemin şekil şartının tamamlanabilmesi açısından önem arz etmektedir. Kamu görevlileri kapsamında yürütülen disiplin soruşturmalarındaki soruşturma raporunda yer alan disiplin cezası teklifi, bu duruma bir örnek olarak gösterilebilmektedir. Soruşturma raporunun bu anlamda hazırlık işlemi kategorisinde olduğunu belirtmek gereklidir ${ }^{39}$.

Danıştay’ın konuya ilişkin ağırlıklı bakış açısını yansıtan bir kararda; “... soruşturma raporu düzenlenmesi tek başına hukuki sebepler doğuran, davacının hukuki durumunda değişiklikler yapan idari davaya konu olabilecek kesin ve yürütülebilir işlemler niteliğini taşımadıkları gibi soruşturma raporu bir bütün olup sonucuyla etki doğurduğundan, raporda yer alan bölümleri ayrıca dava konusu yapma olanağı da bulunmadığından, istemin incelenmeksizin reddi gerekli(dir)" denilerek, tek başına icrai olmayan soruşturma raporunun, tek başına dava konusu edilemeyeceği bir kez daha vurgulanmıştır ${ }^{40}$.

Her ne kadar soruşturma sonucu teklif edilen cezanın tanzim edildiği rapor icrai nitelikte olmasa da, bunun bir hazırlık işlemi olduğu açıktır. Kaya, disiplin soruşturması kapsamında soruşturmacı tarafından düzenlenen ceza teklifi yazısının yol gösterici nitelikte teklif işlemi olduğunu belirtmektedir ${ }^{41}$. Ancak kanaatimizce mevzuatta disiplin soruşturmasına ilişkin düzenlemelerde bir şekil unsuru olarak kendisine yer bulan soruşturma raporundaki ceza teklifi bir hazırlık işlemidir.

37 Danıştay 5 D, E 1976/9152 K 1980/2001, 05.05.1980.

38 Akyılmaz, Sezginer ve Kaya, İdare Hukuku (n 2) 341.

39 Danıștay’ın ağırlıkla bu görüșe sahip olmasının yanı sıra aksi yönde de kimi kararlarının bulunduğunu belirtmemiz gerekir. Konuya ilişkin olarak detaylı bilgi için bakınız; Ender Ethem Atay, 'Müfettişlerin Hazırladıkları Disiplin Soruşturma Raporlarından Dolayı Sorumlu Tutulabilirliği Sorunu’ (2016) 7 Uyuşmazlık Mahkemesi Dergisi $167,175$.

40 Danıştay 2 D, E 2005/2684 K 2007/3695, 05.10.2007 kararından aktaran Atay, 'Müfettişlerin Hazırladıkları Disiplin Soruşturma Raporlarından Dolayı Sorumlu Tutulabilirliği Sorunu’ (n 39) 176.

41 Kaya, 'Türk İdare Hukukunda İcrai Olmayan İdari İşlemler' (n 2) 270. 
Teklif edilen ceza, cezaya karar verecek makamca uygun bulunarak icrai nitelik kazanmaktadır ${ }^{42}$. Devlet Memurları Disiplin Yönetmeliğinnin "Muhakkikin çalışma usulü” başlıklı 29/III. maddesi kapsamında; disiplin raporunun değerlendirme ve kanaat bölümünde, yapılan soruşturma sonucunda tespit edilen disiplin cezasının ne olması gerektiğine dair teklifin yer alması zorunludur ${ }^{43}$. Dolayısıyla karar verilecek disiplin cezasından önce bu teklifin yapılması, mevzuatın ortaya koyduğu bir yükümlülük olması sebebiyle, teklifin burada ana icrai işlemin şekil unsurunu tamamlayan bir öğesi olduğunu belirtmek yerinde olacaktır. İște bu bakımdan da yol gösterici işlem niteliğinde olan teklife dayanılarak yapılan ana icrai işlemde aranması gereken zorunlu bir şekil unsurundan bahsetmememize karşın, hazırlık işlemi niteliğindeki teklifte ise tamamlanması gereken bir şekil unsuru zorunluluğu bulunmaktadır. Ancak her iki işlem türünde de, tesis edilmesine neden oldukları ana icrai işlemin sebep unsurunu oluşturdukları gerçeğini vurgulamamız gerekmektedir.

\section{B. CEVAP NITELIĞINDE YOL GÖSTERICi ișLEM}

İdarenin en temel özelliklerinden birisi resen hareket edebilme gücüdür. İdare, bir idari işlem tesis ederken ilgilinin iradesini aramadan hareket edebilmektedir ${ }^{44}$. Ancak kimi zaman idarece kendisine sorulan bir soru üzerine icrai olmayan cevaplar verilebilmektedir. Bu cevapların verilebilmesi için doğal olarak idareye yapılmış bir başvurunun bulunması gerekecektir.

Sorulan soruların türlerine göre cevapların niteliği de değişime uğramaktadır. İdare kimi zaman icrai bir işleme başlamadan önce başkaca bir idare tarafından sorulan teyit sorusuna, kimi zaman ise kendi uzmanlık alanlarına ilişkin özel ve teknik bilgi gerektiren bilimsel sorulara cevap vermek durumunda kalabilir. Bu soruların dışında, idare dışı ilgililerin sorularına da yol gösterici cevapların verilmesi gerekebilmektedir.

\section{TEYIT TALEBIYLE SORULAN SORUYA VERILEN CEVAP IŞLEMI}

Bireyler ve idareler, bazı durumlarda bir faaliyete başlamadan önce başka idarelere, bu konuda teyit alma talepli soruları yöneltebilirler. Faaliyete geçilmeden alınması istenen teyit, yol gösterici nitelikte olacağ 1 için, yasal bir zorunluluk bulunmasa da ilgililer açısından önem taşıyacaktır. Ayrıca her ne kadar önemini belirtsek bile bu işlemlerin icrai nitelikte olmadığı da vurgulamalıdır.

Teyit talepli sorular, ilgililer tarafından yöneltilen ve soruldukları konuda özellikle ilgililerin aydınlatılma ihtiyaçlarını karşılama amacıyla idarelere yöneltilen sorular olarak karşımıza çıkmaktadır. Bu talepler soru niteliğinde sunulsa da, özlerinde bir faaliyette bulunma ya da bulunmama kapsamında yol gösterme ve bilgi sahibi olma ile teyit alınması ihtiyacının karşılanması amacını içerir. Bu niteliği gereği teyit talepli sorulara verilen cevapların dolaylı bir etkilerinden

42 Atay, 'Müfettişlerin Hazırladıkları Disiplin Sorușturma Raporlarından Dolayı Sorumlu Tutulabilirliği Sorunu' (n 39) 177.

43 Devlet Memurları Disiplin Yönetmeliği, Cumhurbaşkanlığı Karar Numarası: 3935, Karar Tarihi: 29.04.2021, RG 30.04.2021/31470.

44 Yıldırım, Yasin, Kaman, Özdemir, Üstün ve Okay Tekinsoy (n 1) 323. 
bahsedilse de, doğrudan bir etkisi olmadığından bahsetmemiz gerekir. Dolayısıyla icrai bir işlem olmadığını belirtmek gerekir ${ }^{45}$.

Danıştay, bireylerin ilgili idarelere teyit amaçlı sordukları sorulara verilen cevapların icrai niteliğe sahip olmadığını belirtmektedir. Bir işletme tarafından Maliye Bakanlığı’na, imal edilen bir cihazın belli oranda istihsal vergisine tabi olup olmayacağına dair teyit amaçlı soruya, Bakanlıkça verilen cevabın niteliği Danıştay tarafından incelenmiştir. Danıştay bu kapsamda dava konusu işlemle ilgili; “... ortada henüz Gider Vergisini doğuran bir olay vuku bulmadiğının tarh, tahakkuk ve tebliğ işlemlerinin yerine getirilmediğinin, kısaca vergi alacağının doğmadığının, söz konusu müracaat üzerine daval Bakanlikça verilebilecek cevabın sadece bir görüşten ibaret olabileceğinin, nitekim dosyada da bulunan cevabi yazının bir görüş ve mütalaadan ibaret bulunduğunun anlaşılmasına, Danıştay'da ise ancak kesin ve yürütülmesi gerekli nitelikteki işlemlerin dava konusu yapılabilmesinin mümkün olmasına binaen istişari nitelikteki Bakanlık işleminin dava konusu edilmesinde isabet bulunmamaktadır" kararını vermiștir ${ }^{46}$. Böylece Danıştay, teyit amaçlı soruya verilen cevabın doğrudan icrai niteliğinin olmamasını vurgulamış ve bu tür bir işlemin iptal davasına konu edilemeyecek olduğunu da belirtmiştir.

İdareler bazı konularda icrai bir işlemi tesis etmeden önce başka bir idareden ya da aynı idare içinde başka bir idari birimden teyit almak isteyebilirler. Bu teyit talebinin, "istenmesi ve uyulması zorunlu olan” bir danışma işlemi olmasına gerek yoktur ${ }^{47}$. İdare hiyerarşi ilişkisinin doğal gereklerinden kaynaklanan teyit edici bir talepte bulunulabilirken ${ }^{48}$, kimi zaman ise ilgili konuda uzman başkaca bir idareye bu talebini sunabilir. Burada dikkat çeken önemli husus, talepte bulunan idarenin icrai bir işlem yapıp yapmamasını etkileyecek bir teyittin, yasal bir zorunluluğa dayanmamasıdır.

Danıştay da, idareler arasında teyit edici yönde verilen görüşlerin icrai niteliğinin bulunmadığı görüşüne sahiptir. İmar planında ilköğretim yeri olarak tespit edilen ve ayrılan taşınmaz malın, kamulaştırılmaması nedeniyle kamulaştırmadan vazgeçme yönündeki görüş işleminin iptali için açılan iptal davasında Danıştay, işlemin icrai niteliğinin bulunmadığı üzerinde durmuştur ${ }^{49}$. Karar, 3194 sayılı İmar Kanunu ${ }^{50}$ ile birlikte incelendiğinde, ilgili hüküm olan 13/III. maddesi bakımından yasal bir zorunluluk olmayan görüş alınması işleminin icrai niteliğinin bulunmaması nedeniyle iptal davasına doğrudan konu edilemeyeceği açıktır. Kararda ayrıca bu görüşşşleminin iptal davasına konu

45 Mustafa Gündüz, Türk İdare Hukukunda İcrai Nitelikte Olmayan İşlemler (Gazi Üniversitesi Sosyal Bilimler Enstitüsü Yüksek Lisans Tezi, 2016) 73.

46 Danıştay 7 D, E 1975/213 K.1975/2514, 24.12.1975.

47 Erkut (n 2) 174.

48 ibid 174.

49 Danıştay 6 D, E.1994/3836 K.1995/298, 18.01.1995.

50 İmar Kanunu, Kanun Numarasi: 3194, Kabul Tarihi: 03.05.1985, RG 09.05.1985/18749’un “İmar planlarında umumi hizmetlere ve kamu hizmetlerine ayrılan yerler" başlıklı 13/III. maddesi uyarınca; "ilgili mevzuat uyarınca hiçbir şekilde yapr yapilamayacak alanlarda muvakkat da olsa yapı yapılmasina izin verilmez. Mevcut yapilar kamulaştırilincaya kadar korunabilir. Bu alanlarda beş yıllık imar programı süresi içinde, birinci fikranın (a) ve (b) bentlerine göre işlem tesis edilerek parsel, kamu mülkiyetine geçirilmek zorundadır. Bu süre en fazla bir yıl uzatılabilir". Hükümden açıkça anlaşıldığ 1 üzere, umumi hizmetlere ve kamu hizmetlerine ayrılacak yerler bakımından görüş almaya ilişkin bir yasal zorunluluk bulunmamaktadır. 
edilemeyeceğinin tespit edilmesi gerekirken, yerel idare mahkemesinin işlemi bilirkişi incelemesine tabi tutması yerinde bulunmamıştır.

Danıştay teyit amaçlı sorulara verilen görüş cevabının icrai olmadığına ilişkin verdiği bir başka kararda da, idareler arası görüş iletiminin bir öneri olarak kabul edilebileceğini belirtmiştir. Yükseköğretim Kurulu Başkanlığı’na Endüstriyel Sanatlar Eğitim Fakültesi İşletme Eğitimi Bölümü müfredatının karşılaştırılarak Muhasebe ve Finansman alanına kaynaklık teşkil edip edemeyeceği hususunun sorulması üzerine, Başkanlık'tan verilen görüşün nitelendirilmesi bakımından Danıştay incelemede bulunmuştur. Danıştay; “... İşletme Eğitimi Bölümünün müfredatının Muhasebe ve Finansman alanına kaynak teşkil edemeyeceğine dair öneri niteliğindeki kararın, Yükseköğretim Kurulu Başkanlğ̆ı’na sunulduğunun bildirildiği görüllmektedir" kanaatine ulaşmıştır ${ }^{51}$. Danıştay, idari uyuşmazlık konusu olan işlemin öneri niteliğinde olduğunu vurgulamaktadır.

YÖK Başkanlığı’nın kendisine gelen teyit amaçlı sorulara yanıt vermesi, kamu hizmetinin sürekli bir şekilde sağlanması adına da önem taşımaktadır. Bu nedenle kendisine sorulan sorulara teyit amaçlı verdiği cevaplar, yükseköğretim kurumları için son derece önem taşımaktadır. YÖK’ün bu tür cevapları, yasal bir dayanağa bağlı olmasalar bile, icrai nitelikte yapılacak işlemlere de yol gösterecektir. 2547 sayılı Yükseköğretim Kanunu’nun ${ }^{52}$ "Yükseköğretim Kurulunun görevleri” başlıklı 7. maddesi incelendiği zaman, hem genel anlamda yükseköğretim kurumlarının işleyişinin denetlenmesi hem de tüm yurt çapındaki yükseköğretim programlarının koordineli çalışabilmesi adına faaliyette bulunma sorumluluğu göze çarpmaktadır. Dolayısıyla yükseköğretim kurumlarından YÖK’e gelen soruların cevaplanmasında temel bir sorumluluğun olduğu da görülmektedir.

İdareden teyit alabilmek amacıyla sorulan bu sorulara verilecek cevapların yanlış, noksan veyahut yanıltıcı olması durumunda ilgililer açısından ne gibi sorunların oluşacağı da ayrı bir tartışma konusudur. Bu durumda verilen cevabin icrai olup olmaması hususu ve hatta icrai olup olmamasindan da öte işlemin olası hukuki sonuçlarını tespit etmek ayrı bir inceleme gerektirmektedir. Buradaki belirlemede faydalanacağımız ilke ise idareye güven ilkesidir. Hukuk devletinin ayakta kalabilmesi adına idareye güvenin korunması elzemdir. Dolayısıyla idarenin her çeşit faaliyetinde bireylere güven aşılaması gerekir. Bunun içinde idarenin faaliyetlerinde saydam, istikrarlı ve öngörülebilir hareket etmesi gerekir ${ }^{53}$. Kişinin kendisine uygulanacak hukuku önceden bilebilmesi hukuk güvenliğinin gereği olduğu gibi, idarenin kendisine davranışı konusunda önceden bilgi ve öngörü sahibi olması da aynı şekilde hukuk devletinin zorunluluğudur. Bu doğrultuda idarenin olası yanlış, noksan ya da yanıltıcı teyit cevabı, ilgililerin idareye olan güvenini zayıflatarak ilgili üzerinden manevi bir etki yaratabilirken, belki de ilgililerin bu cevaba dayalı başkaca faaliyetleri kapsamında maddi zararlara uğramasına da neden olacaktır. Dolayısıyla ilgililerin idareye karşı zararlarının tazmini bakımından hak sahibi olabilmelerinin de yolu açlabilecektir. Hizmet kusurunun gelenekselleşmiş tanımı içerisinde bulunan şartların ve idarenin sorumluluğunun gerçekleştiğini bu yönde belirtebiliriz.

51 Danıştay 2 D, E 2010/6219 K 2014/2483, 20.03.2014.

52 Yükseköğretim Kanunu, Kanun Numarası: 2547, Kabul Tarihi: 04.11.1981, RG 06.11.1981/17506.

53 İdareye güven ilkesi hakkında detaylı inceleme için bakınız; Harun Yılmaz, Türk İdare Hukukunda İdari İstikrar (1. Baskı, Oniki Levha Yayıncılık, 2019) 45. 
İdarenin yürütmekle görevli olduğu bir idari faaliyette oluşan bozukluk, gecikme veya noksanlık, yürütülen o faaliyetin gereği gibi işlememesi; geç işlemesi veya hiç işlememesine neden olabilecektir ve bu nedenle idarenin kusuru ortaya çıkacaktır ${ }^{54}$. Buradan yola çıktığımızda ise teyit cevabı alınma talebiyle başvuruda bulunulan idarenin hatalı tesis ettiği cevap nedeniyle oluşacak zararlardan da sorumlu olması gerekir.

\section{BIREYLERCE BILGI ALINMAK AMACIYLA SORULAN SORUYA YOL GÖSTERICI CEVAP iŞLEMi}

Kişiler bir işe ya da faaliyete başlamadan önce kimi zaman bir yönlendirmeye ihtiyaç duyabilirler. Özellikle daha önce hiç dâhil olmadıkları bir süreç içerisinde yer alacaklarsa, yollarını aydınlatacak bilgilere ihtiyaçları olabilir. Bu doğrultuda ilgili bir idarenin yol gösterici olması, kişilerin hem hukuka uygun hem de yerinde faaliyette bulunabilmelerini sağlamaktadır.

Kendisine başvuruda bulunan kişilere nasıl ve ne yönde hareket etmelerini belirtmesine yönelik idarenin verdiği cevap işlemi, doğrudan doğruya iptal davasına konu edilebilecek bir icrai idari işlem değildir ${ }^{55}$. Enformel yani bilgi verici bir yol gösterici niteliğe sahip olan bu idari işlemler, idareye başvuru neticesinde tesis edilir ${ }^{56}$. Yapılan bu tip başvurular üzerine idare, kişilere kimi zaman doğrudan, kimi zaman ise mevzuatı yorumlayarak izlenilmesi gereken süreçleri açıklar ${ }^{57}$.

Bireylerce sorulan sorulara yol gösteren bu işlem tipi, başvuru sahibini aydınlatıcı bir fonksiyon taşır. Bu fonksiyonun üzerine çıkış yapılamayacağı da bellidir. Aydınlatıcı bu fonksiyon kapsamında bilgilendirici, gösterici ve yönlendirici, mevzuatı yorumlayıcı, kişilere hak ve yükümlülüklerini bildirici tavsiyelerde bulunulması doğaldır ${ }^{58}$. Tabi bu fonksiyonun yerine getirilmesinde tesis edilen işlemlerin niteliği de incelemeye tabi tutulmalıdır. Bu doğrultuda inceleme yapıldığında, somut bir duruma ilişkin idarece sunulan görüşün icrai nitelikte kabul edilemeyeceği sonucu ortaya çıkar ${ }^{59}$.

İdarenin bireylerin yaptı̆̆ başvurular hakkında, başvurucunun yanlış mercie başvurduğunu ve doğru mercii göstermesinin bu tip bir işlem olduğunu söylemek gerekir. Örneğin tamire muhtaç bir evi olan ve bu kapsamda ne yapılmasını sormak amaçlı belediyeye başvuran şahsa, tamirat izni alınması gerektiğini belirten belediye yazısının icrai olmayan bir yol gösterici işlem olduğu kabul edilir ${ }^{60}$. Danıştay ayrıca, bu işlemin iptal davasında kesin ve yürütülmesi gereken bir idari işlem olmadığına karar vermiştir ${ }^{61}$.

54 Yıldırım, Yasin, Kaman, Özdemir, Üstün ve Okay Tekinsoy (n 1) 837; Akyllmaz, Sezginer ve Kaya, Türk İdari Yargılama Hukuku (n 14) 496; Gürsel Kaplan, İdari Yargılama Hukuku (3. Baskı, Ekin Yayınevi, 2018) 271.

55 Kaya, 'Türk İdare Hukukunda İcrai Olmayan İdari İşlemler' (n 2) 272.

56 Açımuz (n 2) 542.

57 Erkut (n 2) 178.

58 Ender Ethem Atay, İdare Hukuku (4. Bası, Turhan Yayınevi 2014) 436.

59 Hasan Dursun, 'İdari İşlemin İcrailiği (II)’ (2011) 58 (6) Terazi Hukuk Dergisi 40, 75; Açımuz (n 2) 543.

60 Akyılmaz, Sezginer ve Kaya, İdare Hukuku (n 2) 342.

61 Danıştay 6 D, E 1965/137 K.1966/2261, 30.05.1966 kararından aktaran Kaya, 'Türk İdare Hukukunda İcrai Olmayan İdari İşlemler' (n 2) 272. 
Danıştay verdiği bir diğer kararda, yine iptal davasına konu edilebilecek bir işlemin kesin ve yürütülmesi zorunlu olan bir işlem olduğunu belirterek, icrası mümkün olmayan yol gösterici işlem niteliğindeki cevapların iptal davasına konu edilemeyeceğini ifade etmiştir. Kademe farkından doğan alacaklarının ödenmesi için valiliğe başvuran bir ilkokul öğretmenine, yanlış idari birime başvurduğunu belirterek doğru muhatabın Milli Eğitim Bakanlığı olduğunu bildiren cevap yazısının iptali için açılan davada Danıştay görüşünü korumuştur. Kararda “... Valiliğinin yukarıda sözü edilen yazısı davacının doğrudan doğruya Milli Eğitim Bakanlı̆̆ına müracaat etmesini bildiren bir yazı olup ortada kesin ve icrası lazım gelen bir karar yoktur" yönünde kanaate varan Danıştay, yol gösterici niteliği sebebiyle işlemin hukuk dünyasında doğrudan icrai bir etkiye sahip olmadığını yine vurgulamıştır ${ }^{62}$.

\section{BILIMSEL NITELIKTE SORGULAMA AMACIYLA SORULAN SORULARA VERILEN CEVAP iŞLEMi}

İdare, faaliyet gösterdiği uzmanlık alanına ilişkin olarak her zaman sorularla karşılaşabilmektedir. $\mathrm{Bu}$ durumlarda idarenin bu sorulara cevap verme yükümlülüğünün doğacağı da açıktır. İdarelerin ve özellikle hizmet bakımından yerinden yönetim kuruluşlarının çeşitliliğinin fazla olması, soruların uzmanlığa göre ilgiliye yöneltilmesi bakımından da çeşitliliğin artmasını sağlamaktadır. Bu sayede ilgililerin tüm idari teşkilat düşünüldüğünde, cevapsız sorusunun kalmaması sağlanacaktır.

Uygulamanın incelenmesinde, bu tür sorulara yanıt verilebilmesi amacıyla, idarelerin çeşitli idari birimlerinin kurulduğu da görülmektedir. Örneğin 4 numaralı Bakanlıklara Bağlı, İlgili, İlişkili Kurum ve Kuruluşlar ile Diğer Kurum ve Kuruluşların Teşkilatı Hakkında Cumhurbaşkanlığı Kararnamesi’nin Türkiye Radyo-Televizyon Kurumu’nu düzenlendiği 38. Bölümün “Danışma kurulları" başlıklı 539. maddesi kapsamında kurumun görev alanına ilişkin danışmanlık verebilecek kurulların oluşturulabileceği belirtilmektedir ${ }^{63}$. Geçici bir danışmanlık görevine sahip olacak bu kurulların, kamunun sorularına yanıt bulma adına teknik ve ilmi (bilimsel) konularda araştırma yapma ve sonucunu açılkama yükümlülüğüne sahip olması gerekmektedir. Bu yükümlülüğün daha da somutlaşması açısından Türkiye Radyo-Televizyon Kurumu Geçici Danışma Kurulları Yönetmeliği yürürlüğe girmiştir ${ }^{64}$. Yönetmeliğin 5/II. maddesinin ikinci cümlesi uyarınca; “... Radyo ve Televizyon yayınları hakkında kamuoyunun düşünce ve dileklerini tespit etmek üzere ...” bu kurulların görev yapacağı belirtilmiştir. Bu kapsamda yapılacak incelemelerde ortaya çıkacak sonuçların, kamuoyunun sorguladığı ve düşündüğü konuların çözümlenmesi amacıyla elde edilmesinin gerekliliği ortaya

62 Danıştay 5 D, E.1975/3447 K.1975/6663, 31.10.1975.

6330479 sayı ve 15.07.2018 tarihli Resmi Gazetede yayımlanan 4 Sayılı Bakanlıklara Bağlı, İlgili, İlişkili Kurum ve Kuruluşlar ile Diğer Kurum ve Kuruluşların Teşkilatı Hakkında Cumhurbaşkanlığı Kararnamesi’nin 539.maddesi uyarınca; "Yönetim Kurulu veya Genel Müdür tarafindan Türkiye Radyo-Televizyon Kurumunun bu Bölümde belirtilen görevleri çerçevesinde; radyo ve televizyon yayınları hakkında kamuoyunun düşünce ve dileklerini tespit etmek, ilmi veya teknik araştırmalar yaptırmak veya lüzumlu görülecek konularda özel ihtisaslarından yararlanmak maksadıyla geçici danışma kurulları teşkil edilebilir”. Bu hükümden önceki mevzuat hükmü olan 18221 (2. Mükerrer) sayı ve 14.11 .1983 tarihli Resmi Gazete'de yayımlanan 2954 sayı ve 11.11.1983 kabul tarihli Türkiye Radyo ve Televizyon Kanunu'nun 15. maddesi, 703 sayı ve 02.07.2018 tarihli Kanun Hükmünde Kararname’nin 95. maddesi ile ilga edilmiştir.

Türkiye Radyo-Televizyon Kurumu Geçici Danışma Kurulları Yönetmeliği, RG 06.08.2009/27311. 
konmaktadır. Diğer bir deyişle, kamunun sorguladığı konularda teknik ve bilimsel bir araştırma yaparak bir sonuç ortaya koyma yükümlülügünün bu geçici danışma kurullarına verildiği açıktır. Ortaya çıan bu cevapların kesin ve yürütülebilir idari işlemler ile somutlaşmaması durumunda, bu cevaplara karşı iptal davasının açılamayacağını da belirtmek gerekir.

Yarg1 kararlarında da bilimsel nitelikli cevapların icrai olmadığı yönünde görüş bulunmaktadır. Örneğin bir kitap yazma düşüncesi ile ezanın hoparlörden okunmasının bilimsel gerekçesini Din İşleri Yüksek Kurulu’na soran bir başvurucunun aldığı “ibadete çağrı olan ezanın hoparlörle okunmasının gayesine uygun olduğunu, bununla beraber hoparlörün fazla açılmaması gerektiğı" cevabının iptali için açtığı iptal davasında Danıştay, cevabın mütalaa kapsamında bulunduğunu belirtmiştir ${ }^{65}$. Danıştay, cevap türünü icrai olmayan bir işlem olarak belirlemiş ve davanın kesin ve yürütülmesi gereken bir işleme karşı açılmadığını tespit etmiştir.

Her ne kadar icrai niteliği bulunmasa da, bilimsel nitelikli sorgulama sonucu verilecek cevapların, icrai işlemlere etkisinin büyük olduğu yargı kararları ile ifade edilmiştir. Tesis edilecek kimi icrai işlemlerde bilimsel nitelikteki bu icrai olmayan işlemlerin noksanlığı, icrai bir işlemin sebep unsurunda eksikliğe yol açmaktadır. Yargı kararları ile de bu durum tespit edilmekle beraber, icrai işlemin hukuka aykırı olarak tesis edildiği sonucuna varılmaktadır. Danıştay, uzman hekim fikirleri ve bilimsel görüşler alınmadan, aktif relapsing remitting multiple skleroz hastalığının tedavisinde etkin olan Tysabri isimli ilacın kullanım şartlarını sınırlama amaçlı tesis edilen 28597 sayılı ve 24.03.2013 tarihli Resmî Gazete'de yayımlanan Sağlık Uygulama Tebliğinin 4.2.34/III-(b) hükmünün iptali istemiyle açılmış olan davada; “... söz konusu ilacın kullanım şartına ilişkin olarak dava konusu düzenleme ile getirilen sinırlamaları destekleyici nitelikli bilimsel bir görüş de ortaya konulamadığından dava konusu işlemde hukuka uygunluk bulunmadığı sonucuna ulaşılmıştır" kanaatine varmıştır ${ }^{66}$. Bu doğrultuda icrai idari işlem niteliğinde olan tebliğ hükmünü, sebep unsuru sakatllğg gerekçesi ile iptal etmiştir. Danıştay’ı’n da belirttiği üzere, bilimsel incelemeler neticesinde tesis edilen yol gösterici işlemlerin icrai bir idari işlemin sebep unsurunu oluşturabilme özelliği nedeniyle önemi yadsınamaz.

\section{B. BILDIRI / DUYURU / AÇIKLAMA NITELIĞINDE YOL GÖSTERICI IŞLEM}

İdarenin belirli bir konuya dair düşünce, niyet ya da görüşünü belirten, ancak icrai bir sonuç doğurmayan açıklamaları, toplumu ve ilgileri aydınlatma amacıyla yapılabilmektedir. Tavsiyeler, alınması gereken önlemler veya bir konu hakkında fikir belirttikleri bu işlemler, doğrudan hukuki sonuç doğurmamaktadırlar ${ }^{67}$. Açıklayıcı nitelikteki bu işlemler bir hususu aydınlatma amacı ile alınan kararlardan oluşurlar. Dolayısıyla tebliğ ve ilan edilme amaçlarının yanı sıra mevcut bir maddi olguyu ya da hukuki durumu açıklama amacını da güderler.

65 Danıştay 12 D, E 1968/1150 K 1969/702, 10.04.1969'dan aktaran Kaya, ‘Türk İdare Hukukunda İcrai Olmayan İdari İşlemler' (n 2) 273.

66 Danıştay 15 D, E 2017/287, K 2018/6547, 02.10.2018.

67 Yıldırım, Yasin, Kaman, Özdemir, Üstün ve Okay Tekinsoy (n 1) 337. 
Bir başvuru üzerine veya idarece resen tesis edilebilen bu işlemler, kendi başlarına herhangi bir bağlayıcilığa sahip değildirler ${ }^{68}$. Uygulamaya tabi tutulmaları adına, bunlara bağlı bir birel ya da düzenleyici işlemin tesis edilmesi gereklidir. İdari karar niteliğinde olmayan bu açıklamaların hem toplumu hem de ilgili kamu tüzel kişilerini bilgilendirme gayesiyle yapıldığını vurgulamakta fayda vardir.

Kimi zaman idareler, sadece kendileri ile ilişkili kişileri bilgilendirme amacıyla hareket edebilmektedirler. Meslek odalarının üyelerine yol gösterici olarak kimi açılamalarda bulunduğu görülmektedir. Örneğin barolar tarafından avukatlara gönderilmiş olan uyarı ve tavsiyeleri bu kategoride belirtebiliriz ${ }^{69}$. Yine aynı doğrultuda Bakanlıkça yapılacak proje yarışmalarında, Mimarlar Odası Yönetmeliğine uyulması yolundaki Türk Mühendis ve Mimar Odaları Birliği’nin bildirisinin de, kesin ve yürütülebilen bir idari işlem niteliğinde olmadığı belirtilmiştir ${ }^{70}$.

Meslek odalarının somut olaylara ilişkin yaptıkları kınama ya da bilgilendirme metinleri de yine bildiri niteliğinde yol gösterici işlem olarak karşımıza çıkmaktadır. Örneğin İstanbul Barosu tarafından 5199 Sayılı Hayvanları Koruma Kanunu’nun, hayvan hakkı ihlallerini durdurmak, failleri cezalandırmak ve hayvanların haklarını teslim etmek yönündeki toplum beklentisini karşılamakta eksik ve yetersiz kalması sebebi ile hayvan hakları alanında yeni bir yasal düzenleme ihtiyacını belirterek, bu yönde yapılan çalışmalara katkı vermek amacıyla yayınlanan görüş, yol gösterici niteliğe sahipken, icrai bir idari işlem değildir ${ }^{71}$.

Açıklama niteliğinde icrai olmayan idari işlemler kimi zaman, kamu idareleri ya da kamu kurumlarının tesis ettikleri idari işlemler hakkında diğer kamu tüzel kişileri tarafından alınan yerindelik görüşü içerikli kararlar olarak da karşımıza çıkabilmektedir. Kamu Denetçiliği Kurumu’nun vermiş olduğu kararlar bu hususa örnek olarak verilebilir. Kurum kararları, bağlayıcılık niteliğinden yoksundur. 6328 sayılı Kamu Denetçiliği Kurumu Kanunu’nun "Kurumun görevi” başlıklı 5. maddesi uyarınca; "Kurum, idarenin işleyişi ile ilgili şikâyet üzerine, idarenin her türlü eylem ve işlemleri ile tutum ve davranışlarını; insan haklarına dayalı adalet anlayışı içinde, hukuka ve hakkaniyete uygunluk yönlerinden incelemek, araştırmak ve idareye önerilerde bulunmakla görevlidir" ${ }^{72}$. İdareye önerilerde bulunma görevi bulunan Kurumun, bu kararlarını uygulatabilme bakımından yetkisi yoktur. Diğer bir deyişle bağlayıcılık unsurundan yoksun olan bu kararlar, görüş ve açılamadan öteye geçemeyecektir. Ancak bu kararlar kimi zaman başka bir idari işlemin gerekçesi olarak kendilerine yer bulabilirler.

Kamu Denetçiliği Kurumu, Kamu Kurum ve Kuruluşlarında Çalışan Personelin Kılık ve Kıyafetine Dair Yönetmeliğin ${ }^{73}$ 5. maddesinde yer alan "görev mahallinde baş daima açık" ibaresinin, "insan haklarına, eşitlik ilkesine, din ve vicdan hürriyetine, çalı̧̧ma ve sözleșme hürriyetine, adalet anlayışına,

68 Yaşar (n 2) 263.

69 ibid 263.

70 Kaya, ‘Türk İdare Hukukunda İcrai Olmayan İdari İşlemler' (n 2) 273.

71 <https://www.istanbulbarosu.org.tr/HaberDetay.aspx?ID=16442\&Desc=Kamuoyuna-Duyuru> Erişim Tarihi 23.08.2021.

72 Kamu Denetçiliği Kurumu Kanunu, Kanun Numarası: 6328, Kabul Tarihi: 14.06.2012, RG 29.06.2012/28338.

73 Kamu Kurum ve Kuruluşlarında Çalışan Personelin Kılık ve Kıyafetine Dair Yönetmeliği, RG 25.10.1982/17849. 
hukuka ve hakkaniyete, iyi yönetim ilkelerine ve aynı zamanda Anayasa'ya ve uluslararası sözleşmelere aykırıllk teşkil ettiğini belirterek, başörtüsü yasağının kaldırllması ve insanların serbestçe kamu kurum ve kuruluşlarında çalışmalarının olanaklı kılınması" gerekçesi ile metinden çıkarılması yönünde tavsiye kararı almıştır ${ }^{74}$. Bu tavsiye kararı gerekçe gösterilerek Bakanlar Kurulu’nca 4/10/2013 tarihinde; "Elbise, pantolon, etek temiz, düzgün, ütülü ve sade, ayakkabılar ve/veya çizmeler sade ve normal topuklu, boyalı, görev mahallinde baş daima açık, saçlar düzgün taranmış veya toplanmış, tırnaklar normal kesilmiş olur. Ancak bazı hizmetler için özel iş klyafeti varsa görev sırasında kurum amirinin izni ile bu klyafet kullanılır" ibaresi ilga edilmiştir. Somut örnekte de görüldüğü üzere, ilgili idarenin başkaca bir kamu kurumu tarafından verilen tavsiye nitelikli kararını gerekçe göstererek, yeni bir icrai işlem tesis edebileceğini söylemek gerekir. Diğer bir deyişle Kamu Denetçiliği Kurumu’nun kararlarının tavsiye özelliğine sahip olması, bu kararların hiçbir fonksiyona sahip olmayacağı anlamına gelmemektedir ${ }^{75}$. Dolayısıyla özellikle Kamu Denetçiliği Kurumu’nun yol gösterici sınıfta addedilebilecek icrai olmayan tavsiye kararlarının, dolaylı yoldan icrai niteliğe sahip olacağı görülmektedir. Özellikle Kurumun iyi yönetim ilkesi yönünden diğer kamu tüzel kişilerinin faaliyetleri üzerinde denetimde bulunması bakımından verdiği kararların etkinliği yönünden de ne denli önemli olduklarını göstermektedir ${ }^{76}$. Ayrıca tavsiye kararlarının, idari yargı üzerindeki etkisinin de yadsınamaz olduğunu belirtmek gerekir. İdari yargı tarafından yapılacak uyuşmazlık konusunun esasına ilişkin değerlendirmelerde, Kurumun tavsiye kararlarının idari yargı mercilerine yardımcı özelliğe sahip olacağı açıktır ${ }^{77}$.

Kamu Denetçiliği Kurumu’nun bir kararında, idareye yön verici ve yol gösterici nitelikte bir tavsiyede bulunulduğu görülmektedir. Şanlıurfa Barosu tarafından savunma hakkının etkin bir şekilde kullanılabilmesini sağlamak amacıyla kolluk birimlerinde ifade alınması sırasında ifade tutanağında avukat beyanlarına da yer verilmesi ve bu konuda kolluk birimleri arasında uygulama birliğinin sağlanması için gerekli tedbirlerin alınması hususunda İçişleri Bakanlığı’na tavsiyede bulunulmasına ilişkin yapılan başvuruda, Kurum başvuruyu kabul ederek tavsiye kararı vermiştir ${ }^{78}$. Bu doğrultuda merkezi idarenin Kurumun kararı doğrultusunda düzenleyici bir işlem tesis edebileceği de düşünülebilmektedir. Diğer bir deyişle tavsiye niteliğinde verilen karara bağlı olarak, idari işlem ya da işlemler tesis edilebilir.

74 Kamu Denetçiliği Kurumu, 20.08.2013 tarihli tavsiye kararı.

75 Ender Ethem Atay 'Hukuk Devleti İlkesi Işı̆̆ında İdarenin Denetimi ve Kamu Denetçiliği Kurumu' (2014) 1(1) Ombudsman Akademik Dergisi 22; Onur Kaplan, 'Kamu Denetçiliği Kurumu Tarafından Verilen Tavsiye Kararlarının Hukuki İşlevi ve Etkisi' (2020) 7(13) Ombudsman Akademik Dergisi 113.

76 Kamu Denetçiliği Kurumu’nun vermiş olduğu tavsiye kararlarının hukuki niteliğinin detaylı olarak incelenmesine ilişkin olarak detaylı bilgi için bakınız; Kaplan 'Kamu Denetçiliği Kurumu Tarafından Verilen Tavsiye Kararlarının Hukuki İşlevi ve Etkisi' (n 68) 101, 109. Kamu Denetçiliği Kurumu’nun vereceği tavsiye kararlarının idareler üzerindeki etkinliğinin oluşup oluşamayacağı yönünde şüpheler bakımından detaylı bilgi için bakınız: Mutlu Kağıtçıŏglu, 'Kamu Denetçiliği Kurumunu (Türk Ombudsmanını) Yeniden Tasarlamak' (2018) 7(14) Anayasa Hukuku Dergisi 505, 506.

77 Kaplan 'Kamu Denetçiliği Kurumu Tarafından Verilen Tavsiye Kararlarının Hukuki İşlevi ve Etkisi' (n 76) 112.

78 Kamu Denetçiliği Kurumu, 2021/2150 başvuru sayı ve 09.07.2021 tarihli tavsiye kararı. https://d.barobirlik.org.tr/2021/ tbb_202.107.16154657.pdf Erişim Tarihi 05.08.2021. 


\section{YOL GÖSTERICi işLEMIN TEMEL ÖZELLIKLERi}

Yol gösterici icrai olmayan işlemlerin, diğer icrai olmayan işlemlerle ortak bazı temel özellikleri bulunmaktadır. Ancak doğaları gereği diğer icrai işlemlerden ayrılan özelliklerinin de bulunduğunu belirtmek gerekir.

\section{A. DOĞRUDAN BAĞLAYICI NITELIKTE OLMAMASI}

Yol gösterici işlemler bağlayıcı bir fonksiyona sahip değildirler. Hukuk dünyasında bir etki yaratamamalarının yanı sıra, ilgili idareleri bir işlem tesis etmeye zorlama kabiliyetleri yoktur. Görüş ve fikirlerin ifade edildiği bu işlem türünün, bağlayıcılık unsurundan yoksun olduğunu belirtmemiz gerekmektedir.

İcrai bir idari işlemin hukuki etkiye sahip olduğu açıktır ${ }^{79}$. Ancak icrai olmayan yol gösterici işlemde böyle bir etkinin bulunmadığını belirtmek gerekir. Her bir idari işlemin icrai niteliğe sahip olmadığı, aralarında icrai olmayan idari işlemlerinde var olduğu doktrinde kabul görmüş bir düşüncedir ${ }^{80}$. Dolayısıyla doğrudan icrai bir etkiye sahip olmasa bile yol gösterici işlemlerin idari işlem niteliğinin var olmadığını belirtmek yanlış bir ifade olacaktır.

Fransız ve Türk Hukukunda bir işlemin icrailik özelliğinden yoksun olması, daha önce bahsettiğimiz gibi o işlemin iptal davasına konu olabilme durumunu etkilemektedir. Kesin ve yürütülebilir bir icrailiğe sahip olmamaları nedeniyle iptal davasına konu edilemeyecek bir işlem oldukları ayrıca vurgulanmaktadir ${ }^{81}$.

İdareye veya bireylere yol gösterme amacı, bağlayıcılık tartışmasından uzak olarak danışma ve öneri fonksiyonlarını içermektedir. Kılavuzluk eden bu işlemlerin bağlayıcılık niteliğinden yoksun olması bu anlamda yine vurgulanmaktadır ve bu nedenden ötürü doktrinde hukuki değerlerinin ihmal edildiği de belirtilmektedir ${ }^{82}$.

Yol gösterici icrai olmayan işlem türlerinin incelenmesiyle aslında Danıştay’ın da konuya bakış açısı ortaya çıkmıştır. Türleri incelediğimiz bölümde de açıkça görüldüğü üzere, yargı kararlarında bu işlemlerin icrai olmama özellikleri ile bağlayıcılık fonksiyonu arasında doğru orantı kurulmuştur. Diğer bir deyişle idari yargının bu işlem türünü bağlayıcılıktan yoksun olarak gördüğü açıktır. Özellikle kesin ve yürütülmesi gereken bir işlem olmaması yönünde yapılan açıklamalar ile bu durum belirlenmiştir.

79 Akylmaz, Sezginer ve Kaya, İdare Hukuku (n 2) 332.

80 Onur Kaplan, İdari İslem Teorisi Açısından İdare Hukukunda Tespit Edici İşlemlerin Yeri (Oniki Levha Yayıncılık, 2021) 123.

81 Erkut (n 2) 163.

82 Yaşar (n 2) 263. 


\section{B. ICRAi BIR IDARI ISSLEME SEBEBIYYET VEREBILMESi}

Her ne kadar bağlayıcılık fonksiyonu bulunmasa da, bir yol gösterici işlemi gerekçe göstererek yeni bir icrai işlem tesis edilebilir. Bu durumda yol gösterici işlemin bağlayıcılık fonksiyonu bulunmamasına rağmen başka bir icrai işlemine sebebiyet verebileceğinden bahsedebiliriz.

İcrai olmayan bir işlem de olsa yol gösterici işlem, icrai bir işlemin sebep unsurunu oluşturabilir. Bir icrai bir işlemin yapılmasına yol açan hukuki işlem veya maddi olay olarak karşımıza çıkan sebep unsuru, işlemin dayanağını meydana getirir ${ }^{83}$. Bu nedenle icrai bir işlemin olmazsa olmaz unsuru olan sebep unsurunu, kimi durumlarda yol gösterici işlem oluşturabilir.

Bu noktada aslında yol gösterici işlemlerin dayanak olma hususunda da bahsetmek gerekmektedir. Özellikle yönlendirici fonksiyon ile dayanak olma fonksiyonu arasında sıkı bir ilişki olduğunun vurgulanması gerekir ${ }^{84}$. Bir diğer işleme dayanak olabilmesi nedeniyle aslında bir diğer işleme yön vermesi bakımından yol gösterici işlemin önemi oldukça fazladır. Bu nedenle icrai bir işleme sebebiyet verme özelliğinin yadsınamayacağını vurgulamak gerekir.

Kesin ve yürütülmesi gereken bir idari işlemin sebep unsurunu oluşturan yol gösterici işlemin, idari yargı mercii tarafından incelenmesinde hem zorunluluk hem de gereksinim vardır. İcrai idari işlemin neden yapıldığının ortaya çıkması ve hukuka uygunluk denetiminin yapılması bakımından öneme sahip olan yol gösterici işlemlerin bu anlamda göz önünde bulundurulmaları zaruridir.

Yol gösterici işlemler, icrai işlemlerin sebep unsurunu oluşturacak bir niteliğe sahipken, kimi zaman kendilerinden sonra bir icrai işlemin tesis edilmemesi de söz konusu olabilmektedir. Yol gösterici işlemlerin ilgili idarelere sunulmasından sonra, bilgi edinen bu idarelerin herhangi bir icrai işlem tesis etmemesi de gündeme gelebilmektedir. Diğer bir deyişle, yol gösterici işlem ile bilgi edinen idarenin, her bir somut olayın özelliğine göre icrai bir işlem tesis etmesinde zorunluluk bulunmamaktadır.

Danıştay da kararlarında icrai olmayan yol gösterici işlem ile bu işleme bağlı icrai işlemin bir arada değerlendirilmesi gerektiğini belirtmektedir. Danıştay, belediye meclisi tarafından yürürlüğe konmuş bir imar planında dayanak olan nüfus ihtiyacına karşılık gelecek yeterli sosyal ve teknik alt yapının ayrılmadığı hususundaki görüşün, imar planıyla birlikte incelenmesi gerektiği kararını vermiştir ${ }^{85}$.

Sebep oldukları icrai işlemler ile aralarında bağ oluşan icrai işlemlere karşı yargısal başvuru ise kademeli şekilde ilerlemektedir. İcrai işlem olmamaları nedeniyle ilgililer ne kadar yol gösterici işlemlerden etkilenseler de, doğrudan doğruya idari yargıya başvuramazlar. İlgililerin bu durumda uygulayabilecekleri tek çözüm, yol gösterici işlemlerin sebep oldukları icrai işlemlere karşı iptal

83 Yıldırım, Yasin, Kaman, Özdemir, Üstün ve Okay Tekinsoy (n 1) 382.

84 Yol gösterici işlemlerdeki yönlendirici fonksiyon ile dayanak olma fonksiyonu arasındaki sıkı ve benzeşen ilişki hakkında doktrinde ayrıca üzerinde durulan görüşler yer almaktadır. Özellikle yol gösterici işlemler ile tespit edici işlemlerin yakın ilişkiye sahip olması nedeniyle dayanak olma fonksiyonunda da ortak bir özellik karşımıza çıkmaktadır. Tespit edici işlemler hakkında detaylı inceleme için bakınız; Kaplan, İdari İslem Teorisi Açısından İdare Hukukunda Tespit Edici İşlemlerin Yeri (n 80) 277.

85 Danıştay 6 D, E 211/5597 K 2014/565, 30.01.2014'den aktaran Yılmaz, İdari İslemin İcrailik Özelliği (n 2) 69-70. 
davası açmaktır ${ }^{86}$. Bu doğrultuda ortaya çıkan izlenim idarenin yol gösterici işlemlerinin etkisinin olmayacağı değil, bunun yerine bu işlemlere dayanılarak yapılacak işlemler bakımından dolaylı bir etkiye sahip olabilecekleridir ${ }^{87}$.

\section{HERHANGI BIR ŞEKIL ŞARTI ZORUNLULUĞUNUN BULUNMAMASI}

Yol gösterici işlemler incelendiği zaman, belirli bir şekil şartına bağlı olmadan tesis edilebildikleri görülmektedir. Her bir türü açısından geçerli olan bu özellik, bu işlemlerin belirli kalıplara koyulmasına gerek duyulmamasını ve bu sayede işlemin tesis edilmesine kolaylık sağlamaktadır.

Hazırlık işlemlerinden farklı olarak ilgili mevzuatta uyulması gereken şekil zorunluluğu bulunmaması sayesinde idare, amacina uygun olarak yol gösterme fonksiyonunu rahatça kullanabilmektedir. Görüş ve düşüncelerini gerçek kişiler gibi ifade edebilme kabiliyetine sahip olan kamu tüzel kişilerin, belirli sınırlamalara tabi olmadan bu ifade özgürlüğünü kullanabilmeleri, işleyişin hızlanmasını sağlamaktadır.

İdari Usul Kanunu'nun yokluğu, idarenin bu alandaki faaliyetlerini rahatça tesis etmesine neden olmaktadır. Her ne kadar doktrinde bu kanunun yokluğu eleștiriye tabi tutulsa da, kabul edilen görüşlerce idarenin icrai olmayan görüşlerinin tesis edilmesinin zaten bu kanunun kapsamı dışında olması gerektiği belirtilmektedir ${ }^{88}$. Diğer bir deyişler İdari Usul Kanunu’nun ihdas edilmesi söz konusu olsa bile, icrai olmayan yol gösterici işlemlerin bu kanun kapsamına girmeyerek belirli bir usule tabi tutulmaması gerektiği vurgulanmaktadır.

İdari usulün genel kurallarla önceden belirlenmesi, hukuk devletinin temel amaçları arasında yer almaktadır ${ }^{89}$. Ancak kabul etmek gerekir ki, hak ve/veya yükümlülük kurmak yerine bir maddi olguyu ya da hukuki durumu ortaya koyan yol gösterici işlemler bakımından temel amacın faklı olduğunu tekrar belirtmek gerekir. Yol gösterici işlemlerin temel amacının idarenin aydınlatma yükümlülüğünü sağlamak olması, usul ilkelerinin bir adım daha önüne geçmesine neden olmaktadır. $\mathrm{Bu}$ nedenle belirli bir usule tabi olma gereğinin yol gösterici işlemler bakımından uygulanmaması, yol gösterici işlemlerin temel amacının korunmasını sağlamaktadır.

\section{YOL GÖSTERICi IŞLEMIN TESPIT EDICi işLEMDEN AYRI BIR IŞLEM OLMASI}

Yol gösterici işlemin kimi icrai olmayan diğer işlem türleri ile birçok benzerliği bulunmasına karşıllık bazı farlılıklarının bulunduğu da kaçınılmazdır. Benzer nitelikli işlem türlerinden birisi de tespit edici işlemdir.

86 ibid 70.

87 Gül Fiş Üstün, 'Yatırımcıları Koruma Fonu Tarafından Tesis Edilen İdari Para Cezası Bildirim Tutanaklarının Niteliği' (2011) 1(2) Hacettepe Üniversitesi Hukuk Fakültesi Dergisi 70.

88 Yıldırım, Yasin, Kaman, Özdemir, Üstün ve Okay Tekinsoy (n 1) 542.

89 Akyılmaz, Sezginer ve Kaya, İdare Hukuku (n 2) 521. 
Sübjektif (öznel) bir katkıda bulunmadan irade açıklamasını yalın bilgi ile sunan idarenin bu tür işlemi, tespit edici işlem sınıfını oluşturmaktadır. Bilginin verilmesi sırasında belirli bir hukuki durumu veya maddi olguyu açık bir şekilde, idarenin herhangi bir sübjektif katkısı bulunmaksızın sunulması tespit edici işlemin kimliğini ortaya koymaktadır ${ }^{90}$. Bildirici bu niteliklerinden dolayı ilgililer üzerinde ya da hukuk düzeninde herhangi bir değişiklik yapmayan işlemlerdir ${ }^{91}$.

Tespit edici işlemlerin esasını oluşturması bakımından bir işlemde belli bir durumu veya olgunun ortaya çıkarılması gerekir. Diğer bir deyişle idari işlemin mevcut durumu ortaya koyması, o işlemin tespit edici özelliğini ortaya koymaktadır ${ }^{92}$. Bu durum özellikle idarenin irade açılaması ile ortaya çıkacaktır.

Yol gösterici işlemler ile tespit edici işlemlerin ortak yönü, iki tür işlemde de ilgililerin menfaatlerini etkileme vasıflarının olduğudur ${ }^{93}$. Bu kapsamda her ne kadar tek başlarına icrai nitelikte olmasalar da, bu iki tür işlemin icrai işlemlere dayanak olacakları açıktır.

Özellikle bilgi vericilik konusunda yol gösterici işlemler ile benzerliğe sahip olan tespit edici işlemler değerlendirme içeriğine haiz olmamaktadırlar. Tespit edicilik fonksiyonuyla tesis edilen bu işlemlerde düşünsel özelliğinin bulunmaması söz konusudur ${ }^{94}$. İşte bu yönüyle tespit edici işlemlerin, idarenin kendi özgün fikrini açıklama yoluyla tesis ettiği yol gösterici işlemden farklılığının ortaya çıktığını belirtebiliriz.

\section{E. YOL GÖSTERICi işLEMIN IÇ DÜZEN IŞLEMINDEN AYRI BIR işLEM OLMASI}

İdarenin iç işleyişi ve düzeninin sağlanması açısından öneme sahip olan iç düzen işlemleri ${ }^{95}$, icrai olmayan işlem türlerinden biri olarak karşımıza çıkmaktadır. İç düzen işlemleri, hiyerarşi gücü ve yetkisinin irade beyanına dönüşmesi ile ortaya çıkmaktadır ${ }^{96}$. İdare bakımından işleyişe, verimliliğe ve yer, zaman ve yöntemlerde düzeni sağlayan iç düzen işlemleri, diğer icrai olmayan işlemler gibi icrai niteliğe sahip değildirler ${ }^{97}$.

İdare, iç düzen işlem ile tüzel kişilik içerisindeki nizam ve düzeni sağlamayı amaçlar. Bu doğrultuda iç düzen işlemlerine karşı açılacak iptal davalarının doktrinde, idarenin iç çalışma düzeni ile birlikte ilgili idari faaliyetin işleyişinin zedeleneceği ve bu nedenle idarenin olumsuz etkileneceği vurgulanmaktadir ${ }^{98}$.

90 Kaplan, İdari İslem Teorisi Açısından İdare Hukukunda Tespit Edici İşlemlerin Yeri (n 80) 56.

91 Kaya, 'Türk İdare Hukukunda İcrai Olmayan İdari İşlemler' (n 2) 273.

92 Kaplan, İdari İşlem Teorisi Açısından İdare Hukukunda Tespit Edici İşlemlerin Yeri (n 80) 58.

93 Gündüz (n 42) 79.

94 Kaplan, İdari İşlem Teorisi Açısından İdare Hukukunda Tespit Edici İslemlerin Yeri (n 80) 60.

95 İç düzen işlemleri, "hizmet içi işlemler” ya da “iç yazışmalar” isimleriyle de doktrinde anılmaktadırlar; Kaya, “Türk İdare Hukukunda İcrai Olmayan İdari İşlemler’ (n 2) 279.

96 Erkut (n 2) 133.

97 Gündüz (n 45) 87.

98 Erkut (n 2) 140; Kaya, 'Türk İdare Hukukunda İcrai Olmayan İdari İşlemler' (n 2) 279. 
İdarenin iç düzenine ilişkin bu işlemler, yol gösterici işlemlerden farklılı̆̆ını korumaktadır. Bir kamu tüzel kişisi içerisindeki düzenin oluşturulması ana amacıyla oluşturulan iç düzen işlemler ile yol gösterici işlemlerin, tesis edilme amaçları da bu yönde farklılık göstermektedir. Yol gösterici işlem, idareye başvuruda bulunan idare dışı kimselere ya da diğer kamu kurum ve idarelerine yol gösterme amacıyla tesis edilebilmektedir. Bu nedenle işlemin süjesi yönünden açık bir farklılığın oluşacağını da belirtmek gerekir.

\section{SONUÇ}

Hukuk âleminde doğrudan etki yaratan icrai işlemler dışında doğrudan etki yaratmayan işlemler de bulunmaktadır. Bu işlemler icrai olmayan işlemler grubu adı altında bir araya gelirken, her bir alt grup farklı fonksiyonlara sahiptir. İdare, somut durumlara kimi zaman icrai bir işlem için hazırlık işlemi tesis ederken, kimi zaman ise ilgili somut durum üzerine sorulan sorulara yanıt verebilir ya da inceleme yaparak resen bir duyuru yapabilir. İdare, ilgilileri bilgilendirmek amacıyla çeşitli görüş ya da fikir açıklamalarında bulunabilir. İşte bu bakımdan her ne kadar icrai bir işlem tesis etmese de, kişiler ya da kurumlar üzerinde önem arz eden icrai olmayan işlemler tesis etmiş olur. Ayrıca bu işlemler her ne kadar doğrudan icrai bir etkiye sahip olmasalar da, o işlemlerin idari işlem niteliğine sahip oldukları gerçeğini değiştirmez.

İdarenin önemli görevlerinden birisi olan toplumu aydınlatma, bilgi sunma yükümlülüğü, idari usul ilkelerine yerleşmiştir. Bu nedenle idarenin bu görevi yerine getirebilmesi adına yol gösterici işlemlerin tesis edilmesi ve bu işlemlerin amaca uygun olarak ilgililere sunulmasında önem arz eden bir kamu yararının bulunduğunu belirtmek yanlış olmayacaktır.

Kimi zaman bireyler, kimi zaman ise toplum üzerinde önemli sonuçları olan yol gösterici işlemin fonksiyonel olarak çeşitli alt türleri bulunmaktadır. Bu alt türlerin ayrımındaki önem, somut olaylara ilişkin doğru işlemin tesis edilmesini sağlamanın yanı sıra, yargı önüne gelebilecek işlem türlerinin de tespit edilebilirliğini ortaya koymaktır.

Yol gösterici işleminde içinde bulunduğu icrai olmayan işlemler sınıfı bakımından icrai etkilerinin hiç olmadığı yorumunu yapmak, aslında tam olarak doğru olmayabilecektir. Belirli kesin ve yürütülebilecek bir idari işleme sebep olan yol gösterici işlemler her ne kadar doğrudan idari yargıda dava konusu edilemeyecek olsalar bile, yapılacak yargılamada esasa ilişkin kararın verilmesine etki edeceklerdir. Bu durumun yanı sıra yol gösterici işlemlerle ile birlikte geriye kalan tüm icrai olmayan işlemlerin, ilgililer ya da eşyalar üzerinde de dolaylı bir etkilerinin olacağı açıtır.

Kimi iptal davalarında, davaya konu edilen icrai işlemin sebep, amaç ya da şekil unsurunu doğrudan etkileyecek icrai olmayan işlemlerin de yargı yeri tarafından denetlenmesi gerekecektir. Her ne kadar icrai olmayan işlemlerin iptal davasına konu edilip yargı yerince iptal edilmesinin söz konusu olamayacağ 1 kesin olsa da, bu tür işlemlerin yarg1 yerince hukuka uygunluk denetimine tabi tutulmasında hiçbir engel bulunmamaktadır. İcrai olmayan işlemler üzerinde hukuka uygunluk denetiminin yapılması, yargılamada zorunluluktan öte bir gereklilik arz edecektir. Bu kapsamda iptal 
davasına konu edilecek icrai bir idari işlemin sebep unsurunu oluşturan yol gösterici işlemin, idari yargı merciince incelenmesi hem zorunlu hem de gereklidir.

İçtihattan da anlaşılacağı üzere, idari yargı bakımından idarenin tesis ettiği işlemin sadece icrai olup olmadığının tespiti ön plandadır. Yargı yerleri icrai olmayan gösterici işlemin alt gruplarına bakmaksızın ilgili işlemin kesin ve yürütülebilir bir işlem olup olmadığı üzerinde durmaktadır. Diğer bir deyişle, icrai olmayan işlemin alt türünün tespitinden öte işlemin iptal davasına konu olabilirliği idari yargının esas olarak incelediği husustur.

İcrai idari işlemlerin sebep unsurunu oluşturabilecek şekilde bir etkiye sahip olan kimi yol gösterici işlemlerin, kişiler ve eşyalar üzerinde de dolaylı bir etkisi olduğu açıktır. Bu nedenle icrai işleme dayanak oluşturan yol gösterici işlemlerin "dolaylı icrai işlem" niteliğinde olduğunu belirtmek yerinde ve doğru olacaktır.

\section{KAYNAKÇA}

Açımuz B, 'İdarenin Esnek Hukuk İşlemlerinin Yargısal Denetime Konu Edilmesi: Fransız Hukuku Odaklı İnceleme’ (2018) 24(2) Marmara Üniversitesi Hukuk Fakültesi Hukuk Araştırmaları Dergisi 530 - 568.

Akyılmaz B, İdari Usul İlkeleri Işı̆̆ında İdari İ̧slemin Yapılış Usulü (2000).

Akyılmaz B, Sezginer M ve Kaya C, Türk İdare Hukuku (12. Bask1, Savaş Yayınevi 2020).

Akyılmaz B, Sezginer M ve Kaya C, Türk İdari Yargılama Hukuku (4. Baskı, Savaş Yayınevi 2020).

Atay EE, 'Hukuk Devleti İlkesi Işığında İdarenin Denetimi ve Kamu Denetçiliği Kurumu' (2014) 1(1) Ombudsman Akademik Dergisi 1 - 30.

Atay EE, İdare Hukuku (4. Bas1, Turhan Yayınevi 2014).

Atay EE, 'Müfettişlerin Hazırladıkları Disiplin Soruşturma Raporlarından Dolayı Sorumlu Tutulabilirliği Sorunu' (2016) 7 Uyuşmazlık Mahkemesi Dergisi 167 - 182.

Boz SS, İdare Hukukunda Haklı Beklentinin Korunması (Seçkin Yayıncılık 2017).

Duran L, İdare Hukuku Ders Notları, (Fakülteler Matbaası 1982).

Dursun H, 'İdari İşlemin İcrailiği (II)’ (2011) 58(6) Terazi Hukuk Dergisi 40 - 74.

Erkut C, İptal Davasının Konusunu Oluşturma Bakımından İdari İ̧slemin Kimliği, (T.C. Danıştay Yayınları No: 51 2015).

Fiş Üstün G, 'Yatırımcıları Koruma Fonu Tarafından Tesis Edilen İdari Para Cezası Bildirim Tutanaklarının Niteliği' (2011) 1(2) Hacettepe Üniversitesi Hukuk Fakültesi Dergisi 64 - 72.

Giritli İ, Bilgen P, Akgüner T ve Berk K, İdare Hukuku (5. Baskı, Der Yayınevi 2012).

Gözler K, İdare Hukuku Cilt: I (İkinci Baskı, Ekin Yayınevi 2009).

Günday M, İdare Hukuku (İmaj Yayınevi 2011).

Gündüz M, Türk İdare Hukukunda İcrai Nitelikte Olmayan İslemler (Gazi Üniversitesi Sosyal Bilimler Enstitüsü Yüksek Lisans Tezi, 2016).

Kağıtçığlu M, 'İdari İşlemin İcrailiği’ (2012) 103 Türkiye Barolar Birliği Dergisi 267 - 284.

Kağıtçığlu M, 'Kamu Denetçiliği Kurumunu (Türk Ombudsmanını) Yeniden Tasarlamak' (2018) 7(14) Anayasa Hukuku Dergisi 457 - 512.

Kaplan G, İdari Yargılama Hukuku (3. Baskı, Ekin Yayınevi, 2018). 
Kaplan O, 'Kamu Denetçiliği Kurumu Tarafından Verilen Tavsiye Kararlarının Hukuki İşlevi ve Etkisi’ (2020) 7(13) Ombudsman Akademik Dergisi 93 - 119.

Kaplan O, İdari İşlem Teorisi Açısından İdare Hukukunda Tespit Edici İşlemlerin Yeri (Oniki Levha Yayıncılık, 2021).

Karahanoğulları O, İdarenin Hukukla Kavranması: Yasallık ve İdari İşlemler (Yargı Kararlarına Dayalı Bir İnceleme) (4. Bask1, Turhan Kitabevi 2018).

Kaya C, 'Türk İdare Hukukunda İcrai Olmayan İdari İşlemler' (2004) 9(1-2) Gazi Üniversitesi Hukuk Fakültesi Dergisi, 253 - 284.

Sancakdar O, Önüt LB, Us Doğan E, Kasapoğlu Turhan M ve Seyhan S, İdare Hukuku Teorik Çalışma Kitabı (Seçkin Yayınevi 2019).

Sezginer M, İptal Davasının Uygulama Alanı Bakımından Ayrılabilir İşlem Kuramı (Yetkin Yayınları 2000).

Tan T, İdare Hukuku (Turhan Kitabevi 2013).

Yaşar HN, İdare Hukuku (Genel Esaslar) (Der Yayınevi 2014).

Yayla Y, İdare Hukuku (2. Basım, Beta Yayıncılık 2010).

Yıldırım T, Yasin M, Kaman N, Özdemir HE, Üstün G ve Okay Tekinsoy Ö, İdare Hukuku (Güncelleştirilmiş 7. Baskı, Oniki Levha Yayıncılık 2018).

Yılmaz D, İdari İşlemin İcrailik Özelliği (Astana Yayınları 2014).

Yılmaz D, ‘Türk İdare Hukuku’nda İdari İşlemin “Kesinliği” Üzerine Bir Değerlendirme: “Kime Göre?”, “Ne İçin?” Kesinlik’ (2017) 21(2) Gazi Üniversitesi Hukuk Fakültesi Dergisi, 105 - 153.

Yılmaz H, Türk İdare Hukukunda İdari İstikrar (1. Baskı, Oniki Levha Yayıncılık, 2019). 